\title{
The New Debate on the Interpretation of MFN Clauses in Investment Treaties: Putting the Brakes on Multilateralization
}

\author{
By Simon Batifort and J. Benton Heath*
}

\section{ABSTRACT}

This article challenges the conventional wisdom that MFN clauses in investment treaties can always be used to "import" substantive standards of treatment (e.g. FET). It argues that most tribunals permitting this use of MFN clauses have relied on presumptions and have ignored meaningful variations among clauses. It also points out that states are increasingly questioning the conventional view, and that a recent arbitral award has firmly rejected an attempt to use an $M F N$ clause to import substantive standards. It concludes by sketching the terms of the new $M F N$ debate.

The interpretation of Most-Favored-Nation (MFN) clauses in investment treaties has potentially enormous consequences for the scope and extent of states' obligations concerning the treatment of foreign investors. Yet for nearly two decades, the discussion on MFN has been overwhelmed by the controversy sparked by the Maffezini decision, ${ }^{1}$ regarding whether MFN clauses can be used to "import" dispute settlement provisions from one treaty to another. ${ }^{2}$ Meanwhile, a conventional wisdom has taken hold that MFN clauses generally may be invoked by investors to rely on standards of treatment, such as fair and equitable treatment (FET), full protection and security (FPS), or protection from arbitrary or discriminatory measures, which are absent from the applicable investment treaty or present in an allegedly

* Simon Batifort is a member of the International Arbitration Group of Curtis, Mallet-Prevost, Colt \& Mosle in New York and an Adjunct Professor at Brooklyn Law School. J. Benton Heath is an Attorney-Adviser with the United States Department of State in Washington, D.C., and formerly a member of Curtis's International Arbitration Group. The views expressed herein are the authors' own and do not necessarily reflect those of the United States government, or of Curtis or its clients. While at Curtis, the authors were counsel to the respondent in the İckale v. Turkmenistan arbitration discussed in this article. The authors thank Julian Arato, Mathias Forteau, Athina Fouchard Papaefstratiou, Carla M. Greenberg, Justin Jacinto, Andrew Larkin, Charles Leben, Ben Love, Julianne Marley, Donald McRae, Gaelen Perrone, David Sloss, Christina Trahanas, Marat Umerov, Fuad Zarbiyev, the participants in the 2017 ASIL Midyear Meeting Research Forum, and anonymous AJIL reviewers for insightful comments.

${ }^{1}$ See Emilio Agustín Maffezini v. The Kingdom of Spain, ICSID Case No. ARB/97/7, Decision on Objections to Jurisdiction, paras. 43-64 (Jan. 25, 2000) [hereinafter Maffezini].

${ }^{2}$ We use the term "importation" to refer to reliance on a Most-Favored-Nation (MFN) clause in a treaty entered into by a given state (the basic treaty) to obtain the benefit of provisions set forth in other treaties entered into by that state (third-party treaties). Although it is a widely used and convenient shorthand, it does not precisely reflect the operation of MFN clauses. See Christopher Greenwood, Reflections on 'Most Favoured Nation' Clauses in Bilateral Investment Treaties, in Practising Virtue 556, 559-61 (David D. Caron, Stephan W. Schill, Abby Cohen Smutny \& Epaminontas E. Triantafilou eds., 2015) (emphasizing that, as a matter of law, third-party treaty provisions are neither "written into" nor "incorporated" into the basic treaty via an MFN clause) [hereinafter Greenwood]; Zachary Douglas, The MFN Clause in Investment Arbitration: Treaty Interpretation Off the Rails, 2(1) J. Int'l Disp. Settlement 97, 104-05 (2011) (similar) [hereinafter Douglas, Off the Rails]. 
less attractive form. ${ }^{3}$ In line with that conventional wisdom, most tribunals have treated the use of MFN clauses to import substantive treaty obligations as uncontroversial, or even, in the words of one decision, as "universally agreed" and "the very essence of an MFN provision in a BIT." 4

We argue that this conventional wisdom relies on a particularly strong form of "top-down" reasoning, which imposes presumptions as to the nature or essence of MFN clauses in general. ${ }^{5}$ This top-down perspective obscures the variation among MFN clauses in investment agreements and other treaties, and leads interpreters to adopt an unduly uniform approach to the function of MFN provisions. A careful analysis of the text of specific clauses leads to a much more nuanced picture and calls into question the prevailing view that all MFN clauses in investment treaties were designed to import standards of treatment. By bringing our treatyby-treaty, "bottom-up" approach into contact with the prevailing top-down view of MFN importation, we hope to provoke a new debate—one which drives toward a more balanced approach to the interpretation of MFN clauses. ${ }^{6}$

\footnotetext{
${ }^{3}$ On the widespread agreement on the importation of standards of treatment via MFN clauses in investment treaties, see, for example, Ieva Kalnina, White Industries v. The Republic of India: A Tale of Treaty Shopping and Second Chances, 9(4) Transnat'l Disp. Mgmt. 2, 6 (2012) (stating that the MFN debate concerns only "the importation through an MFN clause of dispute resolution mechanisms, whereas the importation of substantive provisions is not at all controversial"); J. ROMESH WeERAMANTRY, TREATY INTERPRETATION IN INVESTMENT ARBITRATION 177 (2012) (observing that importation of standards of treatment is "generally accepted") [hereinafter WeeramantrY]; Scott Vesel, Clearing a Path Through a Tangled Jurisprudence: Most-Favored-Nation Clauses and Dispute Settlement Provisions in Bilateral Investment Treaties, 32 Yale J. InT'L L. 125, 163 (2007) (stating that such importation "has never been seen as problematic") [hereinafter Vesel]; Patrick Dumberry, The Importation of 'Better' Fair and Equitable Treatment Standard Protection Through MFN Clauses: An Analysis of NAFTA Article 1103, 14(1) Transnat'L Disp. Mgmt. at 14 (2017) (noting that there is a "large consensus" on this use of MFN) [hereinafter Dumberry, MFN in NAFTA Cases]; Tomoko Ishikawa, Keeping Interpretation in Investment Treaty Arbitration 'on Track': The Role of State Parties, in Reshaping the Investor-State Dispute Settlement System 115, $129 \&$ n. 68 (Jean E. Kalicki \& Anna Joubin-Bret eds., 2015) (noting a consensus on the use of MFN clauses to import standards of treatment).

${ }^{4}$ Vladimir Berschader and Moïse Berschader v. The Russian Federation, SCC Case No. 080/2004, Award, para. 179 (Apr. 21, 2006) (" $[\mathrm{I}] \mathrm{t}$ is universally agreed that the very essence of an MFN provision in a BIT is to afford to investors all material protection provided by subsequent treaties ....") [hereinafter Berschader]; see also infra Part II; Patrick Dumberry, Shopping for a Better Deal: The Use of MFN Clauses to Get 'Better' Fair and Equitable Treatment Protection, 33 ARB. INT'L 1, 2 \& n. 6 (2017) (reviewing arbitrations other than those conducted under the North American Free Trade Agreement, Can.-Mex.-U.S., Dec. 8, 11, 14, and 17, 32 ILM 289 \& 605 (1993) [hereinafter NAFTA] and stating that "all tribunals have so far accepted the importation of FET protection through MFN clauses") [hereinafter Dumberry, Shopping For a Better Deal].

${ }^{5}$ See, e.g., Patrick Dumberry, The Importation of the FET Standard Through MFN Clauses: An Empirical Study of BITs, 32 ICSID Rev. - ForeIGN Inv. L.J. 116, 131, 134 (2016) (stating that "the very aim of these MFN clauses is to apply to such [substantive] rights") [hereinafter Dumberry, Importation]; KenNeth Vandevelde, Bilateral InVESTMENT TREATIES 360 (2010) (“[P]luck[ing] rights from another agreement and transport[ing] them into this agreement . . . is precisely the function of the MFN treatment provision.") [hereinafter VANDEVELDE]; José Antonio Rivas, Application of Substantive Treaty Obligations via the Most-Favored-Nation Clause: ICSID Case Law Evolution, in A Revolution in the International Rule of Law: Essays in Honor of Don Wallace, Jr. 433, 454 (Borzu Sabahi, Nicholas J. Birch, Ian A. Laird \& José Antonio Rivas eds., 2014) (arguing that "unless otherwise provided by the basic treaty, an investor may rely on the MFN clause to invoke substantive obligations of third-party treaties") [hereinafter Rivas]; Stephan W. Schill, Multilateralizing Investment Treaties Through MostFavored-Nation Clauses, 27 Berkeley J. InT'L L. 496, 506 (2009) (adapted from Stephan W. Schill, The MULTILATERALIZATION OF INVESTMENT LAW (2009)) (advocating "a (rebuttable) presumption that the clauses incorporate more favorable treatment concerning procedure and jurisdiction relating to investor-State dispute settlement just as they apply to substantive standards") [hereinafter Schill].

${ }^{6}$ We are presenting the "top-down" and "bottom-up" approaches not as two hermetically sealed schools of thought, but rather as two endpoints on a continuum. In practice, individual arbitrators and commentators frequently blend top-down and bottom-up elements in varying proportions in their approaches to MFN clauses. We
} 
The stakes of this debate are much higher than simply selecting the proper interpretation of a single clause in a single dispute. For some, the use of MFN to import substantive standards of treatment forms a key legal basis for the "multilateralization" of international investment law. ${ }^{7}$ On this view, MFN provisions in investment treaties "lock States into the most favorable level of investment protection reached at one point of time." ${ }^{8}$ Thus, it is argued that the use of MFN to import other treaty provisions undermines "the understanding of BITs as an expression of quid pro quo bargains," and transforms them into "instruments of multilateralism in international investment relations." 9

This concept of MFN has significant consequences for the regime of investment protection. According to proponents of multilateralization, the presence of MFN clauses in treaties limits the ability of states, for reasons of domestic or foreign policy, to negotiate different agreements with different treaty partners. ${ }^{10}$ It has also been argued that broad applications of MFN clauses by tribunals could make it difficult for states parties to investment agreements to predict their scope of potential liability, as the "combinations and permutations" of investment protections resulting from MFN importation may be "impossible to foresee or administer." 11 And it is suggested that expansive applications of MFN could undermine efforts-now underway in a variety of fora — to "rebalance" investment agreements through renewed attention to the scope and effect of other substantive provisions. ${ }^{12}$

Given these implications, it is important to pause before presuming that generally worded MFN clauses were designed to reorder the matrix of substantive protections that have been afforded in any given treaty. To be sure, some have identified benefits that may be produced by this approach to MFN, such as the simplification of treaty negotiations, ${ }^{13}$ and the

argue that the past two decades of arbitral practice have tilted heavily toward the top-down end of this continuum, and we focus here on providing a counterweight. We are grateful to one of our anonymous reviewers for emphasizing the distinction between top-down and bottom-up approaches.

7 Schill, supra note 5, at 501-06; see also VANDEVELDE, supra note 5, at 360 ("MFN treatment provisions generalize treaty rights and thereby eliminate distinctions in the type of treatment provided to investments or investors of different nationalities .... .”); Christian Leathley, InTERnATIONAl Dispute Resolution In Latin America 18 (2007) ("BITs might mistakenly be seen as mutually exclusive treaties of a bilateral nature. The reality is that the MFN clause has created a network, whereby BITs constitute portals, through which investors can access the highest common standards available.").

${ }^{8}$ Schill, supra note 5 , at 568 .

${ }^{9} \mathrm{Id}$. at 504.

${ }^{10}$ E.g., id. at 568-69; see also United Nations Conference on Trade and Development, Most-Favoured-Nation Treatment, UNCTAD SERIES ON IsSUES IN INTERNATIONAL INVESTMENT AgREEMENTS II, at 105 (2010) (stating that the automatic importation of provisions from third-party treaties through MFN clauses may "create a sense of uniformity of standards when real variations in scope, content and intent exist for very good policy reasons") [hereinafter UNCTAD MFN Report]; Rohan Perera, The Most-Favoured Nation Clause and the Maffezini Case, paras. 99-100 (UN International Law Commission [hereinafter ILC] Study Group on the MFN Clause, Working Paper) (arguing that "a BIT represents clear policy objectives of safeguarding the interests of both investors as well as host States," which constitutes "[a] critical factor" when deciding whether to "import more favourable procedural or substantive provisions"). The Maffezini tribunal noted this possibility in a passage that suggests some discomfort with the implications. See Maffezini, supra note 1, para. 63 (suggesting that "elements of public policy" should limit the operation of MFN provisions, adding that "a distinction has to be made between the legitimate extension of rights and benefits by means of the operation of the clause . . . and disruptive treaty-shopping that would play havoc with the policy objectives of underlying specific treaty provisions . ..").

${ }^{11}$ UNCTAD MFN Report, supra note 10, at 105-06.

12 See, e.g., Catherine Titi, Most-Favoured-Nation Treatment, Survival Clauses and Reform of International Investment Law, 33 J. INT'L ARB. 425, 427-33 (2016) [hereinafter Titi].

${ }^{13}$ See, e.g., David D. Caron \& Esmé Shirlow, Most-Favored-Nation Treatment: Substantive Protection, in Building International Investment Law: The First 50 Years of ICSiD 399, 408-13 (Meg Kinnear, 
furtherance of economic liberalization and equalization of competitive opportunities. ${ }^{14}$ But critics may see these perceived benefits as being offset by the costs to states in terms of predictability and stability in their treaty relations, and the concern is even raised that "a broad MFN obligation might practically ignore the sovereign freedom of States to conclude international obligations as they see fit." 15 These risks are compounded if broad effect is given to MFN provisions on the basis of presumptions about the nature of such clauses, rather than on an assessment of the intended meaning of the particular MFN clause at issue.

There is already some movement to qualify or reconsider the prevailing presumptions about MFN clauses as they relate to the importation of standards of treatment. Some authors have pointed out that interpreters should proceed treaty by treaty, with sensitivity to limitations on the scope of particular MFN clauses, while avoiding generalizations about what "the" MFN clause provides. ${ }^{16} \mathrm{~A}$ more granular approach to the interpretation of MFN provisions is also suggested by the report that the International Law Commission (ILC) recently issued on the topic, which, while expressly reserving judgment on the importation of standards of treatment, ${ }^{17}$ analyzes extensively the potential implications of variations in the text of such clauses. ${ }^{18}$

Geraldine R. Fischer, Jara Minguez Almeida, Luisa Fernanda Torres \& Mairée Uran Bidegain eds., 2015) (“At the point of negotiation, the inclusion of an MFN clause arguably reduces the burden on the negotiating parties to review their treaty partner's prior treaty practice. This is because, generally speaking, any better protections or concessions afforded by the treaty partner in existing treaties of the same class would be incorporated by reference through the MFN clause.") [hereinafter Caron \& Shirlow].

${ }^{14}$ Schill, supra note 5, at 555-56 (discussing these effects in the context of importing dispute settlement provisions); see also José E. Alvarez, A BIT on Custom, 42 N.Y.U. J. InT’L L. \& Pol. 17, 55 (2009) (“MFN guarantees of BITs and FTAs also help ensure that uniform high standards prevail at least among foreign investors, and make attempts to discriminate among foreign investors difficult."). With respect to the desire on the part of some negotiators to ensure uniformity of standards of treatment across bilateral investment treaties, see, for example, Kenneth J. Vandevelde, The Bilateral Investment Treaty Program of the United States, 21 CorNeLL J. INT'L L. 201, 211-13 (1988) [hereinafter Vandevelde, BIT Program].

${ }^{15}$ UNCTAD MFN Report, supra note 10, at 105 (noting these criticisms).

16 See, e.g., Tomoko Ishikawa, Interpreting the Most-Favoured-Nation Clause in Investment Treaty Arbitration, in Rethinking International LaW and Justice 127, 130 (Charles Sampford, Spencer Zifcak \& Derya Aydin Okur eds., 2015) (challenging "the widely accepted position that an MFN clause, unless accompanied by explicit reservations and exceptions, generally allows the 'incorporation' of more favourable substantive provisions in third-party treaties" and arguing that "the interpretation of an MFN clause should be guided by established rules of treaty interpretation, rather than policy considerations regarding the function of 'MFN obligations in general") [hereinafter Ishikawa]; Greenwood, supra note 2, at 558-59 (arguing that "the essential question for a tribunal is not what effect 'the MFN clause' - in a generalized and abstract sense - might have, but what this MFN clause in this particular BIT means and, thus, what effect it has," and emphasizing that interpreters must take into account variations not only in the text of MFN clauses but also in context, purpose, drafting history, and practice of the parties) (emphasis in original); Caron \& Shirlow, supra note 13, 408-13 (noting that, even though it is "widely accepted" that MFN clauses can function as "substantive protection obligation[s]," such MFN claims are usually unsuccessful because of express or implied restrictions in the wording of MFN clauses and constraints arising out of the provisions of the target treaty); Tony Cole, The Boundaries of Most Favored Nation Treatment in International Investment Law, 33 MrCH. J. INT'L L. 537, 540-41, 543 (arguing that a "teleological interpretation" of MFN clauses "as being primarily a means of eliminating discrimination within a given market ... risks allowing the goal of market equalization to override the operation of the MFN clause itself," and emphasizing "the need to attend to the specific details regarding each MFN clause, rather than relying for interpretative purposes on some predecided teleological conclusion") [hereinafter Cole].

${ }^{17}$ ILC, Final Report of the Study Group on the Most-Favored-Nation Clause, para. 80, UN Doc. A/70/10, Annex (2015) (identifying, but not taking up, the "larger question of whether any rights contained in a treaty with a third State, which are more beneficial to an investor, could be relied upon by such an investor by virtue of the MFN clause") [hereinafter ILC 2015 Report].

18 See id., paras. 161-211 (performing this analysis in the context of the Maffezini debate); id., para. 173 (cautioning against making "assumptions about the nature of investment agreements or of the rights that are granted under them"). 
These nascent shifts in the literature dovetail with recent developments in practice. In 2016, the tribunal in İçkale v. Turkmenistan held, for the first time in a published investment treaty case, ${ }^{19}$ that the claimant could not invoke an MFN clause to import standards of treatment, basing its ruling on the particular (but by no means peculiar) wording of the clause at issue. ${ }^{20}$ In parallel, some states, acting as litigants, non-disputing parties, and treaty drafters, have in several instances taken the position that certain common terms in MFN clausessuch as "treatment" or "like circumstances"- do not necessarily permit the importation of substantive standards from third-party treaties. ${ }^{21}$ Taken together, these developments suggest some discomfort with the use of MFN to rearrange the framework of substantive protection in investment treaties, as well as an effort to steer tribunals away from generalized assumptions about "the" MFN clause and back to a more attentive consideration of the specific provision at issue.

We take the opportunity presented by these developments to examine more broadly the legal foundations of the use of MFN clauses to import standards of treatment, and to critically analyze investment treaty jurisprudence on this issue. We begin in Part I by noting the wide variation among MFN clauses in investment treaties and their precursors, both in terms of their text and their potential uses, and the problems that this variation poses for efforts to develop a unified approach to their interpretation. In Part II, we observe that tribunals on both sides of the post-Maffezini debate have applied a particularly strong form of the topdown approach, which relies on a perceived dichotomy between procedure and substance, to arrive at the conclusion that importation of standards of treatment using MFN is unproblematic. In the following parts, we discuss more recent developments that may mark a turn away from the top-down approach. Part III discusses the award rendered in 2016 in $\dot{I}_{\text {çkale, }}$ which rejected importation of standards of treatment after emphasizing the specific terms of the clause at issue. And Part IV connects the turn in $\dot{I}_{\text {çkale }}$ to trends in the practice of some states - in their roles as litigants, non-disputing parties, and treaty drafters-which likewise emphasize the need for close attention to the details of MFN clauses, in ways that may restrict the ability of investors to import standards of treatment. In Part V, we conclude by suggesting that these developments may provoke a new debate on the scope and effect of MFN clauses in investment treaties, and we briefly sketch the terms of the new MFN debate.

\section{I. "There Is No Such Thing as the Most-Favoured-Nation Clause”}

The interpretation of MFN clauses has long been marked by a tension between "bottomup" and "top-down" approaches. The bottom-up approach is reflected in Lord McNair's axiom that "there is no such thing as the most-favoured-nation clause: every treaty requires independent examination." 22 The top-down approach, by contrast, follows from the view

\footnotetext{
${ }^{19}$ United Nations Conference on Trade and Development, Investor-State Dispute Settlement: Review of Developments in 2016, IIA Issues Note No. 1: International Investment Agreements (2017), UN Doc. UNCTAD/DIAE/PCB/2017/1, n. 227 (May 2017) ("The [İ çkale] tribunal's interpretation finds no precedent in prior reported decisions.").

${ }^{20}$ İçkale İnşaat Limited Şirketi v. Turkmenistan, ICSID Case No. ARB/10/24, Award (Mar. 8, 2016) (Veijo Heiskanen (President), Carolyn Lamm, Philippe Sands) [hereinafter İckale].

21 See infra Part IV.

22 Arnold Duncan McNair, The Law of Treaties 285 \& n. 1 (1938) (emphasis in original); see also id. ("There are of course many forms of this clause, so that any attempt to generalize as to the meaning and effect
} 
that the parties to an agreement have something in mind—a generally understood "MFN standard"-when incorporating these provisions into their agreements. ${ }^{23}$ This tension is arguably built in the contemporary rules on treaty interpretation, which direct drafters to the "ordinary meaning" of the treaty terms in their context and in light of the treaty's object and purpose, but also provide that a "special meaning shall be given to a term if it is established that the parties so intended." 24

In the following sections, we draw out this tension between the variation among MFN provisions and the tendency toward top-down approaches to MFN importation of standards of treatment. First, we present a general overview of MFN clauses in investment treaties, noting the variation both in the terms of MFN clauses and in the uses to which they have been put. Second, we turn to key MFN cases and practice from the era preceding contemporary investment arbitration, which influenced the tribunals that first permitted importation of third-party treaty provisions via MFN clauses in investment treaties. We conduct a reexamination of these earlier authorities and argue that they counsel greater caution in the interpretation of MFN clauses than is sometimes appreciated.

\section{A. The Various Terms and Purposes of MFN Clauses}

MFN is not a customary international law standard, and it is thus effected only through specific treaty provisions. ${ }^{25}$ Treaty practice has resulted in an impressive variety of MFN

of the most-favoured-nation clause must be accepted with caution.”); Endre Ustor, Most-Favoured-Nation Clause, in 3 Encyclopedia of Public International LaW 468 (1997) (quoting Lord McNair approvingly); ILC 2015 Report, supra note 17, para. 149 (noting that "each MFN provision must be interpreted on the basis of its own wording and the surrounding context," and that "there is no basis for concluding that there will be a single interpretation of an MFN provision applicable across all investment agreements"); Institut de Droit International, Tokyo Resolution on Investment Treaty Arbitration, Art. 12 ("Most favoured nation treatment requires interpretation of the specific wording of the clause of the treaty in which it is inserted, in order to respect the intentions of the States parties."); Peter T. Muchlinski, Multinational Enterprises \& The Law 630 (2d ed. 2007) (similar); OECD, International Investment Law: A Changing Landscape 158 (2005) (similar) [hereinafter OECD, CHANGING LANDSCAPE]; Ishikawa, supra note 16, at 136 (arguing that tribunals "should base their analysis on established rules of treaty interpretation, rather than on policy considerations concerning the function of 'an MFN clause"'); Greenwood, supra note 2, at 558-59 (noting that even identically worded clauses vary sufficiently in their context, object and purpose, or negotiating history to warrant diverging interpretations).

${ }^{23}$ E.g., Georg Schwarzenberger, The Most-Favoured-Nation Standard in British State Practice, 22 BRIT. Y.B. INT'L L. 96, 104 (1945) ("Though there is no such thing as the m.f.n. clause, it is equally necessary to emphasize that there is such a thing as the m.f.n. standard. As has happened in the case of the minimum standards of international law, the m.f.n. standard owes its clarification to innumerable individual treaties by which it has been developed. The application of the m.f.n. standard in inter-State relations depends on agreement to this effect. Yet the m.f.n. standard and its four inherent elements are clear and definite enough to permit the determination of controversies between parties to such agreements.") (emphasis in original) [hereinafter Schwarzenberger]; Douglas, Off the Rails, supra note 2, at 99 (“'MFN' is a term of art in international law and treaty obligations employing this term of art have an ancient pedigree. When state parties enter into modern investment treaties with an MFN clause, they surely do not intend to relegate the received wisdom on the nature, scope and effect of such clauses to the dustbin of history."); cf. Vandevelde, BIT Program, supra note 14, at 213 (pointing out that not all variations in drafting were meant to have material effects, and reflecting the "concern that any modification, even the elimination of redundancy, might be interpreted as a substantive concession").

${ }^{24}$ Vienna Convention on the Law of Treaties, Art. 31, May 23, 1969, 1155 UNTS 331 [hereinafter Vienna Convention]; Schill, supra note 5, at 549-50 \& n. 231 (noting the "interplay" between these provisions in the context of MFN clauses, and observing that the rules of treaty interpretation give "preponderant weight" to the ordinary meaning of treaty terms).

${ }^{25}$ E.g., Report of the International Law Commission on the Work of Its Thirtieth Session, Art. 7, UN Doc. A/33/10, II(2) Y.B. INT'L L. Comm’N (1978) [hereinafter ILC 1978 Draft Articles]. 
clauses in agreements relating to trade, investment, consular relations, and other matters. ${ }^{26}$ The key feature uniting these diverse provisions is an undertaking by one treaty party to accord treatment to the other states parties (or their nationals) that is no less favorable than the treatment accorded to the most favored third-party state (or its nationals). ${ }^{27}$

In investment treaties, this undertaking is sometimes phrased affirmatively and other times in negative terms. For example, the ILC's final 2015 report on the topic refers to the following clauses from the Austria-Czechoslovakia and U.K.-Argentina investment treaties:

Each Contracting Party shall accord investors of the other Contracting Party treatment no less favourable than that accorded to its own investors or investors of a third State and their investments. . . .

Neither Contracting Party shall in its territory subject investments or returns of investors or companies of the other Contracting Party to treatment less favourable than that which it accords to investments or returns of its own investors or companies or to investments or returns of nationals or companies of any third State. ${ }^{28}$

The ILC identifies six main design elements in MFN clauses. ${ }^{29}$ These are: (1) language that refers "simply to 'treatment' accorded to the investor or the investments"; 30 (2) language "referring to 'all' treatment"; 31 (3) language that relates the term "treatment" to "specific aspects of the investment process, such as 'management,' 'maintenance,' 'use,' and 'disposal' of the investment"; 32 (4) language that connects the MFN obligation to another standard of treatment, such as FET; 33 (5) express provisions that "MFN treatment is to be provided only

${ }^{26}$ See, e.g., ILC 2015 Report, supra note 17, para. 7 ("The Commission had to respect the fact that MFN provisions come in a variety of forms and uniformity in interpretation or application could not necessarily be expected."); Andrew Newcombe \& Lluís Paradell, Law and Practice of InVestment Treaties: Standards of Treatment 199 (2009) (noting that this diversity limited the ILC's ability to codify a definitive set of principles governing MFN clauses). On the diversity of MFN clauses even within investment treaties, see Marie-France House \& Fabrizio Pagani, Most-Favoured-Nation Treatment in International Investment Law, 3-5 (OECD Working Paper No. 2004/2, Sept. 2004) (providing a sample of MFN clauses in investment treaties and noting that "the universe of MFN clauses in investment treaties is quite diverse"); OECD, CHANGING LANDSCAPE, supra note 22, at 158 (noting that "the formulation and application of MFN clauses varies widely among investment treaties").

27 See, e.g., ILC 1978 Draft Articles, supra note 25, Arts. 4-5.

${ }^{28}$ ILC 2015 Report, supra note 17, paras. 56-57 (quoting the Agreement Concerning the Promotion and Protection of Investments (Austria-Czechoslovakia), Art. 3(1), Oct. 15, 1990, 1653 UNTS 19, and the Agreement for the Promotion and Protection of Investments (U.K.-Arg.), Art. 3(1), Dec. 11, 1990, available at http://investmentpolicyhub.unctad.org). As noted by the ILC, both of these clauses are compounded with an obligation to provide national treatment. See id., para. 57.

${ }^{29}$ Id., paras. 59-65. The ILC Report refers to these as "types" of treaty obligation, but, as the report acknowledges, more than one of these elements may be present in any particular MFN provision. Id. Therefore, for the purposes of treaty interpretation, it may be more helpful to think of these as varying elements of treaty text rather than as six ideal types.

${ }^{30}$ Id., para. 60 (citing the Austria-Czechoslovakia bilateral investment treaty (BIT) quoted above).

${ }^{31}$ Id., para. 61 (citing Agreement on the Reciprocal Promotion and Protection of Investments (Spain-Arg.), Art. IV(2), Oct. 3, 1991, 1699 UNTS 187 ("In all matters governed by this Agreement, such treatment shall be no less favourable than that accorded by each Party to investments made in its territory by investors of a third country.")).

${ }^{32}$ Id., para. 62 (citing NAFTA, supra note 4, Art. 1103(2) ("Each Party shall accord to investments of investors of another Party treatment no less favorable than that it accords, in like circumstances, to investments of investors of any other Party or of a non-Party with respect to the establishment, acquisition, expansion, management, conduct, operation, and sale or other disposition of investments.")).

33 Id., para. 63. 
to those investors or investments that are 'in like circumstances' or 'in similar situations' to investors or investments with which a comparison is being made"; 34 and (6) express territorial limitations. ${ }^{35}$ These elements are not exhaustive, and an MFN clause may include other terms and limitations, such as express carveouts for tax treatment or treatment resulting from participation in a customs union. ${ }^{36}$

Claimants in investment treaty arbitrations have attempted to use MFN clauses for several purposes, which can be grouped in two main categories. First, investors sometimes claim that a state has breached an MFN provision, resulting in damage to the investor, by taking measures that allegedly favor nationals from other foreign countries. ${ }^{37}$ This type of claim was made in Parkerings $v$. Lithuania, in which the claimant argued that state authorities discriminated against it in favor of another foreign investor involved in the same economic activitythe construction and management of parking garages. ${ }^{38}$ The Parkerings tribunal accepted in principle that the MFN provision at issue could be applied to remedy the alleged discrimination, but ultimately decided that, on the facts, the two foreign investors were not "in like circumstances." 39 This application, which has been referred to as the "more traditional" use of

${ }^{34}$ ILC 2015 Report, supra note 17, para. 64 (citing NAFTA, supra note 4, Art. 1103 (quoted above) and Agreement Concerning the Reciprocal Promotion and Protection of Investments (Turk.-Pak.), Art. II(2), Mar. 16, 1995 ("Each Party shall accord to these investments, once established, treatment no less favourable than that accorded in similar situations . . . to investments of investors of any third country . ...”)). This requirement, when not expressly stated, is often said to be implied. See, e.g., UNCTAD MFN Report, supra note 10, at 26 (“[B]y not making a specific reference to 'like circumstances' or any other criteria for comparison, the Contracting Parties do not intend to dispense with the comparative context, as it would distort the entire sense and nature of the MFN treatment clause."); Campbell McLachlan, Laurence Shore \& Matthew Weiniger, International Investment Arbitration: Substantive Principles, at para. 7.311 (2d ed. 2017) ("Many treaties do not contain such qualifying language, yet the establishment of a qualifying class for purposes of comparison is inherent in the MFN test.") [hereinafter McLachlan, Shore \& Weiniger]; Andreas R. Ziegler, Most-Favoured-Nation (MFN) Treatment, in Standards of Investment Protection 59, 75 (August Reinisch ed., 2008) (similar) [hereinafter Ziegler].

${ }^{35}$ ILC 2015 Report, supra note 17, para. 65 (quoting Agreement on the Promotion and Protection of Investments (It.-Jordan), Art. 3(1), July 21, 1996, available at http://investmentpolicyhub.unctad.org ("Both Contracting Parties, within the bounds of their own territory, shall grant investments effected by, and the income accruing to, investors of the other Contracting Party no less favourable treatment than that accorded to investments effected by, and income accruing to, its own nationals or investors of Third States.”)).

36 See, e.g., ILC 2015 Report, supra note 17, para. 66.

37 See, e.g., Caron \& Shirlow, supra note 13, at 407 ("MFN clauses have also been used as substantive protection standards in their own right, prohibiting host States from according more favorable treatment to nationals of third States vis-à-vis the claimant protected under the base treaty. Any such finding of breach will give rise to State liability and an obligation to compensate the investor on account of the less favorable treatment it has received. While this function of MFN clauses is overwhelmingly accepted in principle, no awards are publicly available in which an investor has succeeded in such a claim before an ICSID tribunal.").

${ }^{38}$ Parkerings-Compagniet AS v. Republic of Lithuania, ICSID Case No. ARB/05/8, Award, paras. 362-74 (Sept. 11, 2007).

${ }^{39}$ Id., paras. 374-430; see also, e.g., Cargill, Incorporated v. United Mexican States, ICSID Case No. ARB(AF)/05/2, Award, paras. 224-34 (Sept. 18, 2009) (rejecting the MFN claim because the claimant had failed to show that it was in "like circumstances" with third-party investors that allegedly received better treatment with respect to import permit requirements) [hereinafter Cargill]; Grand River Enterprises Six Nations, Ltd., et al. v. United States of America, UNCITRAL, Award, paras. 156-72 (Jan. 12, 2011) (similar); Apotex Holdings Inc. and Apotex Inc. v. United States of America, ICSID Case No. ARB(AF)/12/1 (hereinafter Apotex], Award, paras. 8.59-.77 (Aug. 25, 2014) (similar). 
$\mathrm{MFN},{ }^{40}$ is akin to a "national treatment" claim, except that the applicable comparators are investors from third-party states rather than the host state. ${ }^{41}$

Second, investors have attempted to use MFN clauses to effectively alter the terms of the applicable investment treaty by referring to treaties between the respondent state and third parties. Investors have relied on MFN provisions to: (1) expand the standards of treatment already present in the basic treaty; ${ }^{42}$ (2) claim the benefit of standards of treatment absent from the basic treaty; ${ }^{43}$ (3) circumvent defenses available to the respondent state under the basic treaty; ${ }^{44}$ (4) circumvent provisions relating to preconditions to international arbitration in the basic treaty; ${ }^{45}$ (5) expand the scope of the state's consent to arbitration; ${ }^{46}$ and (6) expand the treaty's scope ratione materiae ${ }^{47}$ or ratione temporis. ${ }^{48}$ These uses can all be described — admittedly with a degree of imprecision—as "importation." 49

The prevailing discourse on the interpretation of MFN clauses in investment treaties has focused on the "importation" category. The terms of this debate largely turn on which of the above forms of importation generally are permitted by the MFN clause, and which generally are excluded. At times, this argument is made from an expressly top-down perspective. ${ }^{50}$ But even where tribunals recognize the need for a "treaty by treaty" (i.e., bottom-up) approach,

\footnotetext{
${ }^{40}$ Meg Kinnear, A Further Update on Most-Favoured-Nation Treatment_In Search of a Constant Jurisprudence, in Contemporary Issues in International Arbitration and Mediation 15, 39 (Arthur W. Rovine ed., 2010) (referring to Parkerings and similar cases as involving "more traditional claims of MFN") [hereinafter Kinnear]; see also Rudolf Dolzer \& Christoph Schreuer, Principles of International InVestment Law 207 (2d. ed. 2012) (observing that "most cases involving the MFN rule have concerned situations in which benefits granted in treaties with third states were invoked" but that " $\mathrm{t}]$ he situation is less complex, and more comparable to the issues in the trade area, when parties to an investment treaty [dispute] do not refer to a treaty with a third party but simply argue that nationals of third parties are treated de facto in a more favourable manner").

${ }^{41}$ See, e.g., Cargill, supra note 39, para. 228 ("[T] he requirement for MFN treatment tracks that of the national treatment requirement. Accordingly, it must be demonstrated first that the Claimant, as an investor, is in 'like circumstances' with the investor of another Party or of a non-Party, or that the Claimant's investment is in 'like circumstances' with the investment of an investor of another Party or of a non-Party. And second, it must be shown that the treatment received by Claimant was less favourable than the treatment received by the comparable investor or investment."); ADF Group Inc. v. United States of America, ICSID Case No. ARB(AF)/00/1, Award, para. 157 (Jan. 9, 2003), 18(1) ICSID REV. - ForEIGN INV. L.J. 195 (2003) (“The Investor did not sustain its burden of proving that the U.S. measures imposed (de jure or de facto) upon ADF International, or the steel to be supplied by it in the U.S., less favorable treatment vis-à-vis similarly situated domestic (U.S.) fabricators or the steel to be supplied by them in the U.S.”).

42 See, for example, the Chemtura case discussed infra in Part IV.A, which involved such an attempt.

${ }^{43}$ See, for example, the White Industries case discussed infra in Part II.B, which allows such an attempt.

${ }^{44}$ See, e.g., CMS Gas Transmission Company v. The Argentine Republic, ICSID Case No. ARB/01/8, Award, para. 377 (May 12, 2005) (rejecting this use of MFN).

45 See, e.g., Maffezini, supra note 1 (allowing this use of MFN).

46 See, e.g., Plama Consortium Limited v. Republic of Bulgaria, ICSID Case No. ARB/03/24, Decision on Jurisdiction, paras. 183-227 (Feb. 8, 2005) (rejecting this use of MFN) [hereinafter Plama].

47 See, e.g., Société Générale in Respect of DR Energy Holdings Limited and Empresa Distribuidora de Electricidad del Este, S.A. v. The Dominican Republic, LCIA Case No. UN 7927, Award on Preliminary Objections to Jurisdiction, para. 41 (Sept. 19, 2008) (rejecting this use of MFN).

48 See, e.g., Técnicas Medioambientales Tecmed, S.A. v. United Mexican States, ICSID Case No. $\mathrm{ARB}(\mathrm{AF}) / 00 / 2$, Award, para. 69 (May 29, 2003) (rejecting this use of MFN).

49 See supra note 2.

${ }^{50}$ See in particular the debate between Zachary Douglas and Stephan Schill on importation of dispute settlement provisions, in which both authors agree that MFN clauses should be interpreted to a significant extent (though not exclusively) by reference to "general principles." Douglas, Off the Rails, supra note 2, at 99; Stephan W. Schill, Allocating Adjudicatory Authority: Most-Favored Nation Clauses as a Basis of Jurisdiction-A Reply to Zachary Douglas, 2 J. InT'L Disp. Settlement 353, 357 (2011) [hereinafter Schill, Adjudicatory Authority].
} 
they may not practice what they preach: one study observed in 2011 that decisions on the scope of MFN clauses depended less on the specific terms or context of the treaty at issue than on the tribunal's presumptions concerning the scope and effect of these clauses. ${ }^{51}$ Indeed, we have found that it is almost always assumed that the importation of substantive standards of treatment (uses (1) and (2), above) is permitted by the MFN clause. ${ }^{52}$ Uses (3)-(6) are more controversial.

The degree of consensus on this point, and the tendency toward top-down interpretative approaches, are striking in light of the significant degree of variation among the text of MFN clauses in investment treaties. This diversity would normally demand caution and sensitivity to variances in meaning - an approach, in other words, that is consistent with the emphasis on "ordinary meaning" and context in the general rules of treaty interpretation. ${ }^{53}$ But the debate on MFN clauses in investment treaties is heavily influenced by the view that "the MFN standard is among the most ancient and venerable in international law," 54 and participants in the debate thus frequently turn to "received wisdom" as to "the nature, scope and effect" of the MFN clause. ${ }^{55}$ It therefore serves to turn briefly to earlier disputes over MFN clauses in commercial treaties, culminating in the Ambatielos case, which have been influential in cementing the view that MFN clauses in investment treaties can be presumed to allow the importation of standards of treatment.

\section{B. MFN Importation in the Pre-BIT Era}

Prior to the advent of contemporary investment treaties, MFN clauses frequently appeared in bilateral commercial treaties, which regulated a variety of matters between nations, usually relating to trade, consular assistance, and the treatment of aliens. ${ }^{56}$ These MFN clauses were

51 Julie A. Maupin, MFN-Based Jurisdiction in Investor-State Arbitration: Is There Any Hope for a Consistent Approach?, 14 J. INT'L ECON. L. 157, 161, 179 (2011) (finding, in the context of decisions on the importation of jurisdictional provisions, that the outcome "has depended primarily neither upon the type of MFN question asked nor upon the specific text of the MFN clause considered" but rather on a "fundamental difference in the burden of persuasion": "tribunals finding in favor of MFN-based jurisdiction (the Maffezini line of cases) have tended to allow such jurisdiction unless persuaded that the contracting state parties to the BIT actively intended to exclude it. Tribunals reaching the opposite result (the Plama line of cases), by contrast, have tended to exclude MFN-based jurisdiction unless persuaded that the contracting state parties specifically intended to include it."); see also International Law Commission, Most-Favored-Nation Clause: Report of the Working Group, para. 29, UN Doc. A/CN.4/L.719 (July 20, 2007) ("Treaty interpretation does not take place in a vacuum. How an interpreter approaches an MFN clause will depend in part on how the interpreter views the nature of MFN clauses.”).

${ }^{52}$ See supra the introduction and infra Part II. We will at times refer to these two uses of MFN clauses collectively as "importation of standards of treatment" or, as a shorthand, "MFN importation."

${ }^{53}$ This has been emphasized in some recent cases dealing with the importation of jurisdictional provisions. See, e.g., HICEE B.V. v. The Slovak Republic, UNCITRAL, PCA Case No. 2009-11, Partial Award, para. 149 (May 23, 2011) (reasoning that it would be "a fallacy to suppose that there existed some general concept that could be called into play to determine the scope of most-favoured-nation treatment in particular cases").

${ }^{54}$ Vladimir Berschader and Moïse Berschader v. The Russian Federation, SCC Case No. 080/2004, para. 17 (Apr. 21, 2006) (Weiler, dissenting) ("As Professor Schwarzenberger observed approximately six decades ago, the MFN standard is among the most ancient and venerable in international law, placing the prospective talents of every other country's drafter at the disposal of the parties to a treaty who agree to include such a provision in their agreement.").

55 Douglas, Off the Rails, supra note 2, at 99. To be clear, Douglas is cautious about over-expansive interpretations of MFN provisions, and refers to this "received wisdom" to support the view that MFN clauses should not be used to import dispute settlement provisions.

56 See, e.g., ILC 2015 Report, supra note 17, para. 11; Kenneth J. Vandevelde, A Brief History of International Investment Agreements, 12 U.C. DaVIs J. Int'L L. \& Pol’y 157, 158-61 (2005); Claire CréPet Daigremont, La 
often specifically drafted to endow the beneficiary of the clause with whatever "privileges," "favors," "immunities," or "liberties" were later granted to a third state, within a defined sphere of activity. ${ }^{57}$ It was argued at the time that this type of clause would accord any benefits within the scope of the clause-such as access to new ports- that were later extended under a new treaty to a third-party state. ${ }^{58}$

In the 1950s, the United Kingdom, the United States, and Greece sought to use these earlier forms of MFN clauses to import standards from third-party treaties in three high-profile cases: Anglo-Iranian Oil Co., Rights of U.S. Nationals in Morocco, and Ambatielos. ${ }^{59}$ The lessons of those cases on MFN for the importation of standards of treatment in investment treaties are, to say the least, not clear-cut. First, it is notable that none of these decisions permitted the claimant to obtain via MFN the benefit of a provision in a third-party treaty, although they suggested that this application of MFN could be permissible under those treaties in other circumstances. ${ }^{60}$ Second, and perhaps more importantly, the MFN clauses at issue in these cases differ substantially from those found in most contemporary investment treaties. For example, the clause at issue in Ambatielos stated:

The Contracting Parties agree that, in all matters relating to commerce and navigation, any privilege, favour, or immunity whatever which either Contracting Party has actually

ClaUSE DE LA NATION LA PLUS FAVORISÉE 81-100 (2015) (reviewing the origins, practice, and eventual decline of MFN clauses in treaties relating to consular relations and the treatment of aliens).

57 See, e.g., Endre Ustor, Special Rapporteur, First Report on the Most-Favoured-Nation Clause, para. 17, UN Doc. A/CN.4/213 (Apr. 18, 1969) (quoting Article 8 of a commercial treaty negotiated between England and France in 1713 ("It is further agreed and concluded, as a general Rule, That all and singular the Subjects of each Kingdom, shall, in all Countrys and Places, on both sides, have and enjoy at least the same Privileges, Libertys, and Immunitys, as to all Dutys, Impositions, or Customs whatsoever, relating to Persons, Goods and Merchandizes, Ships, Freight, Seamen, Navigation and Commerce; and shall have the like Favour in all things as the Subjects of France, or any other foreign Nation, the most favour'd, have, possess and enjoy, or at any time hereafter may have, possess or enjoy.")). Some of these same textual elements appear centuries later in the MFN provision of the 1947 General Agreement on Tariffs and Trade, which provides, with respect to customs duties, charges, and related matters, that "any advantage, favour, privilege or immunity granted by any contracting party to any product originating in or destined for any other country shall be accorded immediately and unconditionally to the like product originating in or destined for the territories of all other contracting parties." General Agreement on Tariffs and Trade, Art. I, Oct. 30, 1947, 55 UNTS 194.

${ }^{58}$ Shinya Murase, The Most-Favored-Nation Treatment in Japan's Treaty Practice During the Period 1854-1905, 70 AJIL 273, 283 (1976) (observing that MFN clauses in nineteenth-century treaties with Japan proved an obstacle to the revision of that country's agreements with the United States, because "all the benefits to be accorded to the United States under a proposed new treaty, such as opening of more ports, would be automatically extended to all the other powers under the MFN clauses contained in their [commercial] treaties [with Japan]. Besides, the United States could still claim the old tariff rate under its own MFN clause unless all the other powers conceded to the new regime."); see also Treaties and Conventions Concluded Between Japan and Foreign Nations, Together with Notifications \& Regulations Made from Time to Time, 1854-1870 (1871) (collecting many of the treaties discussed in Murase's study); Kenneth J. Vandevelde, The First Bilateral InVestment TREATIES 239-40, 261 (2017) (noting, in a similar vein, the concern among some partners to U.S. postwar commercial treaties that MFN provisions would require them to extend national treatment on certain matters to various "feared" third-country investors).

59 See Anglo-Iranian Oil Co. Case (U.K. v. Iran), 1952 ICJ Rep. 93 (July 22) [hereinafter Anglo-Iranian]; Case Concerning Rights of Nationals of the United States of America in Morocco (Fr. v. U.S.), 1952 ICJ Rep. 176 (Aug. 27) [hereinafter Rights of U.S. Nationals]; Ambatielos Case (Greece v. U.K.), 12 ReP. InT'L Arb. AwARDS 83, 107 (Mar. 6, 1956) [hereinafter Ambatielos].

60 See Ambatielos, supra note 59, at 107; Rights of U.S. Nationals, supra note 59, at 190, 204; id. at 226 (Hackworth, Badawi, Levi Carneiro \& Sir Benegal Rau, dissenting); Anglo-Iranian, supra note 59, at 122 (McNair, sep. op.); id. at 141 (Hackworth, dissenting); id. at 144 (Read, dissenting); id. at 157, 170 (Levi Carneiro, dissenting). 
granted or may hereafter grant to the subjects or citizens of any other State shall be extended immediately and unconditionally to the subjects or citizens of the other Contracting Party; it being their intention that the trade and navigation of each country shall be placed, in all respects, by the other on the footing of the most favoured nation. ${ }^{61}$

There is no a priori reason to presume that modern investment treaties, which use substantially different language, are meant to mimic in all respects the scope and effect of these distinct treaty provisions. Investment treaties define their scope with terms such as "treatment of investments" and "like circumstances," and they generally do not contain any express language as to their effect, other than to provide that the parties "shall" provide treatment no less favorable (or, conversely, that they "shall not" provide less favorable treatment). ${ }^{62}$ In contrast, the above-quoted provision refers to "any privilege, favour, or immunity" granted to a third country, and specifically provides that its effect is to "extend[]" those advantages to the beneficiary state "immediately and unconditionally." ${ }^{63}$ Given these substantial differences in treaty texts, it is open to argument whether the parties to contemporary investment treaties intended to follow in all respects the same path as these earlier agreements. ${ }^{64}$

Third, these earlier cases give careful attention to the particular wording of the MFN clause at issue. This is evident in particular in Ambatielos, which of the three cases noted above addresses the MFN clause in the greatest detail. In that case, Greece contended that it was entitled by virtue of the above-quoted clause to invoke a provision referring to "the principles of international law" and various other treaty provisions relating to the "administration of justice" in treaties between the United Kingdom and third countries. ${ }^{65}$

The Arbitral Commission rejected both of these attempts on the basis of a detailed analysis of the particular MFN clause at issue. As to the "principles of international law" provision, the

${ }^{61}$ Ambatielos, supra note 59, at 106; see also Rights of U.S. Nationals, supra note 59, at 190 ("The commerce with the United States shall be on the same footing as is the commerce with . . . the most favored nation for the time being. . . . [W] [Watever indulgence, in trade or otherwise, shall be granted to any of the Christian Powers, the citizens of the United States shall be equally entitled to them."). The MFN clause at issue in Anglo-Iranian did use the term "treatment," but it differed in other respects from contemporary MFN clauses in investment treaties. See Anglo-Iranian, supra note 59, at 108 ("The High Contracting Parties engage that . . the treatment of their respective subjects, and their trade, shall also, in every respect, be placed on the footing of the treatment of the subjects and commerce of the most-favoured nation.").

${ }^{62}$ See supra Part I.A. For a suggestion that MFN provisions in investment treaties thus require an assessment of whether the extension of different treaty provisions to third parties "actually causes a damage to the investor," see UNCTAD MFN Report, supra note 10, at 102.

${ }^{63}$ Ambatielos, supra note 59, at 106; see also Rights of U.S. Nationals, supra note 59, at 190 (providing that "the citizens of the United States shall be equally entitled to" indulgences granted to certain other powers). All three MFN clauses also contain language stating that the beneficiary of the provision shall be placed on the "same footing” with third countries. See Ambatielos, supra note 59, at 106; Rights of U.S. Nationals, supra note 59, at 190; Anglo-Iranian, supra note 59, at 109.

${ }^{64}$ Former officials involved in the drafting of international investment agreements have taken diverging views on this question. Compare VANDEVELDE, supra note 5, at 360 (supporting the view that MFN clauses may be used to "pluck" provisions from third-party treaties), with Alejandro Faya Rodriguez, The Most-Favored-Nation Clause in International Investment Agreements—A Tool for Treaty Shopping?, 25 J. INT'L ARB. 89, 101-02 (2008) (“As a general rule, the MFNC should not be used for treaty shopping purposes. The only exception would be that the third provision relates to competitive conditions for investment; examples would be pre-establishment, transfers and performance requirements. Almost if not all the remaining provisions normally contained in IIAs relate to generic legal standards of protection and procedure, which, because of their nature, should not fall into the [MFN clause].") [hereinafter Rodriguez]. In this respect, see also infra Part IV.B (noting efforts in recent treaties to scale back the scope and effect of MFN provisions).

${ }^{65}$ Ambatielos, supra note 59, at 108-09. 
Commission found that this clause did not constitute the type of "privileges, favours and immunities" referred to in the MFN provision, and therefore could not be invoked by virtue of MFN. ${ }^{66}$ Regarding the "administration of justice" provisions, the Commission determined that in principle the MFN clause was broad enough to reach such provisions, stressing the treaty text manifesting the parties' "intention that the trade and navigation of each country shall be placed, in all respects, by the other on the footing of the most favoured nation." 67 Nevertheless, the Commission found that the treaties invoked by Greece in fact did not contain any "privileges, favours or immunities" more extensive than those set forth in the basic treaty between Greece and the United Kingdom, and therefore the MFN clause had "no bearing on the present dispute." 68

The Arbitral Commission reached these conclusions after analyzing the text, context, and purpose of the applicable provisions, in a manner that tracks the ordinary rules of treaty interpretation. In particular, the Commission stated what has become known in MFN cases as the principle of ejusdem generis: "[The MFN clause] can only attract matters belonging to the same category of subject as that to which the clause itself relates." ${ }^{69}$ Although this principle is often presented as a special rule governing the interpretation of MFN clauses, it is simply an elaboration of the general principle embodied in the Vienna Convention that one must look at the specific terms of a treaty provision to determine its scope and effect. ${ }^{70}$ In the words of one commentator, the ejusdem generis principle "does not in fact provide a rule. . . [W] hat it says in effect is that the scope of the MFN clause is what the MFN clause says it is." 71

Following the landmark cases of the 1950s, efforts to establish general principles governing the scope and effect of MFN clauses, beyond the ordinary rules of treaty interpretation, have been largely unsuccessful. In 1978, the ILC completed a set of draft articles on MFN clauses, which it commended to the members of the UN General Assembly for conclusion of a treaty. ${ }^{72}$ No conference was ever convened, and no treaty was concluded. ${ }^{73}$ Since 1978 ,

${ }^{66}$ Id. at 108; see also S. E. K. Hulme, The Ambatielos Case, 1 Melbourne U. L. Rev. 64, 70 (1957-1958) ("Whether a most-favoured nation clause can have the effect of assuring to its beneficiaries treatment in accordance with the general rules of international law, the Commission expressly left undecided. It was clear that this mostfavoured-nation clause in its express terms covered only 'any privilege, favour or immunity'.") (emphasis in original).

${ }^{67}$ Ambatielos, supra note 59, at 107 (emphasis in original). Several judges had accepted the United Kingdom's contrary position on this point in the earlier proceeding before the International Court of Justice (ICJ) regarding the obligation to refer the Ambatielos case to an arbitral commission. See Ambatielos Case (Greece v. U.K.), 1953 ICJ Rep. 10, 34 (May 19) (McNair, Basdevant, Klaestad \& Read, dissenting). The ICJ majority did not express a view on this point.

${ }^{68}$ Ambatielos, supra note 59, at 109-10. One member of the Ambatielos Commission dissented on this point, as he considered that one of the treaties invoked by Greece contained more favorable provisions. Id. at 129 (Spiropoulos, dissenting).

${ }^{69}$ Ambatielos, supra note 59, at 107.

${ }^{70}$ Vienna Convention, supra note 24, Art. 31(1); ILC 1978 Draft Articles, supra note 25, at 30 (observing that the ejusdem generis principle "follows clearly from the general principles of treaty interpretation"). See also infra Part II.B.4 (discussing the different formulation of the ejusdem generis principle in the Al-Warraq case).

${ }^{71}$ Joshua P. Meltzer, Investment, in Bilateral and Regional Trade Agreements 215, 236 (Simon Lester \& Bryan Mercurio eds., 2009).

${ }^{72}$ ILC 1978 Draft Articles, supra note 25, at 16.

${ }^{73}$ See, e.g., UN General Assembly Decision 46/416 (Dec. 9, 1991) (deciding only to "bring the draft articles on most-favoured-nation clauses, as contained in the report of the Commission on the work of its thirtieth session, to the attention of Member States and interested intergovernmental organizations for their consideration in such cases and to the extent as they deemed appropriate"). 
the context in which MFN clauses are used has changed significantly, owing in large part to the rise of international investment agreements. ${ }^{74}$ As one commentator has noted, the 1978 Draft Articles "provide little insight into the questions raised in contemporary arbitrations."75 To the extent that they can be used as an "interpretative aid" or as "general principles" applicable to MFN clauses in investment treaties, as some have argued, ${ }^{76}$ those Draft Articles do not purport to define the specific benefits that are covered by a given MFN clause, other than by reference to the terms of the clause itself. ${ }^{77}$

For advocates of the top-down approach, the foregoing history of MFN clauses supplies examples of a continuing practice of states claiming that MFN clauses entitle them to invoke provisions set forth in third-party treaties, and of adjudicators seeing no conceptual difficulty with such claims. On this view, the MFN clauses incorporated into modern investment treaties-however reformulated from the more ornate language of earlier trade and consular agreements - participate in the same practice of generalizing treaty standards across bilateral relationships.

We draw a different lesson from these historical examples. The cases of the 1950s stress careful attention to the terms governing the scope and effect of MFN clauses, rather than reliance on preconceived notions of the clause's nature or purpose. And, once we turn to the text, we find significant differences in treaty language across space and time, both among investment treaties and between contemporary investment agreements and their predecessors. In light of this variation, we see little reason to approach MFN provisions in investment treaties with a preconceived notion of the essential purpose or nature of these provisions. There are of course lessons to be learned from the efforts of courts and of the ILC to grapple with MFN clauses. But the most important lesson is that there is no single MFN clause; we must proceed case by case.

\section{The Conventional View on MFN Importation of Standards of Treatment}

Contemporary investor-state tribunals, however, have tended to apply a strong presumption that MFN clauses may be used to import standards of treatment. This view emerges from the confluence of two factors. The first, as we discussed above, is the longstanding pull toward top-down approaches to MFN clauses, which is fueled by an understandable desire for some degree of uniformity and predictability in a field populated by bilateral rather than multilateral treaties. ${ }^{78}$ The second is a reductive schematic — which has emerged in the particular context of investment treaty arbitration - that imposes a rigid distinction between importation of "procedural" and "substantive" provisions. Together, the top-down approach and the procedure/substance dichotomy have fostered what might be called a "sticky default" view on the

${ }^{74}$ This is expressly acknowledged in the ILC 2015 Report, supra note 17, paras. 20-23.

${ }^{75}$ Vesel, supra note 3, at 136.

${ }^{76}$ See, e.g., Schill, Adjudicatory Authority, supra note 50, at 360-61.

${ }^{77}$ ILC 1978 Draft Articles, supra note 25, Art. 9 (providing that the beneficiary of the MFN clause may acquire "only those rights which fall within the limits of the subject-matter of the clause").

${ }^{78}$ See, e.g., Schill, Adjudicatory Authority, supra note 50, at 357 (expressing a "belief in international investment law being a system, in which consistency, coherence, and predictability are core values," and arguing that "the interpretation of BITs should take into account the general principles of international law and interpret every BIT, and every provision within those BITs, in conformity with general international law and in light of the jurisprudence of investment treaty tribunals on comparable clauses in other BITs"). 
use of MFN clauses to import standards of treatment: tribunals and commentators tend to presume that states parties to investment treaties have agreed to this use of MFN, unless the treaty provides otherwise. ${ }^{79}$

This apparent presumption in favor of MFN importation reflects the intuition that it better-and thus "more favorable" - for a treaty to contain an FET provision, or other protection, than to lack that provision. But this bypasses the question whether the applicable MFN clause allows for this possibility. As we noted above, the clauses at issue in contemporary investment treaty cases do not expressly state that any third-country treaty provision that is considered "more favorable" is automatically imported into the basic treaty and may be invoked by a claimant in an arbitral proceeding. These provisions, instead, use terms such as "treatment" and "in like circumstances," which must be interpreted and applied to a given case. As we will see, the cases dealing with importation of standards of treatment tend to address these elements in only a cursory way, if they do so at all.

In this section, we explore the development by arbitral tribunals of this apparent presumption favoring MFN importation of standards of treatment. As we demonstrate in Section A below, the cases that set the terms of the debate regarding MFN importation did not even deal directly with substantive provisions, but rather with the different question of importing dispute resolution provisions. These cases were nevertheless influential in consolidating and entrenching the view that MFN clauses, by default and unless otherwise provided, allow for importing standards of treatment. We then show in Section B that the decisions allowing claimants to import standards of treatment have generally relied-implicitly or even explicitly - on this supposed default rule, and generally have not turned to the text of the clause, except to satisfy themselves that the presumption in favor of importation had not been overcome.

\section{A. The Seeds of the Conventional Wisdom: The Dispute Settlement Cases}

The conventional wisdom on MFN importation can be traced to the earliest investment tribunal decisions concerning MFN and dispute settlement provisions. In 2000, the tribunal in Maffezini v. Spain famously permitted an investor to use MFN to avoid a local-litigation requirement in the Spain-Argentina BIT. ${ }^{80}$ This was the first published investment treaty case to permit the importation of treaty provisions, whether substantive or procedural, via MFN. In addressing the question of importation, the Maffezini tribunal relied on the Ambatielos case discussed earlier. ${ }^{81}$

\footnotetext{
${ }^{79}$ On the concept of "sticky defaults" as applied to investment treaties, see Julian Arato, The Logic of Contract in the World of Investment Treaties, 58 William \& Mary L. Rev. 351, 363 (2016) (citing Ian Ayres, Regulating Opt-Out: An Economic Theory of Altering Rules, 121 YALE L.J. 2032, 2087 (2012)) ("Sticky defaults . . can be contracted around, but doing so requires more concerted action than with ordinary defaults - typically some requirement of clear statement or via the adoption of certain formalities in the contract.").

${ }^{80}$ Maffezini, supra note 1, para. 64.

${ }^{81}$ Id., paras. 48-53; see also supra Part I.B. The Maffezini tribunal also referred to the AAPL $v$. Sri Lanka case, but found it inapposite because the claimant was not invoking MFN in connection with dispute settlement provisions but "only" with respect to "the liability standards." Maffezini, supra note 1, para. 51. In AAPL, the tribunal rejected the claimant's attempt to use an MFN clause to circumvent provisions in the basic treaty relating to compensation for losses caused by war or civil disturbance, finding that it had failed to demonstrate that the absence of such provisions in a third-party treaty constituted more favorable treatment. The tribunal, however, accepted in principle the role of the MFN clause as an "implied incorporation method[]" that may lead to an "extension of the applicable legal system.” Asian Agricultural Products Ltd. (AAPL) v. Republic of Sri Lanka, ICSID Case No. ARB/87/3, Final Award, paras. 21-22, 26(D), 43, 54 (June 27, 1990).
} 
Four years later, the Salini v. Jordan tribunal rejected a similar attempt to use MFN to attract more favorable dispute resolution procedures. ${ }^{82}$ With respect to Ambatielos, the tribunal noted that the case did not concern the importation of more favorable dispute resolution provisions, but rather an attempt by Greece to rely via MFN on "substantive provisions" in other treaties concerning the administration of justice. ${ }^{83}$ In other words, the Salini tribunal found this prior case unhelpful because it did not deal with the particular problem of importing procedural or jurisdictional provisions.

Through repetition of this dichotomy between procedure and substance, the postMaffezini debate "reinforced the notion that investors may invoke substantive right[s] through the MFN clause." ${ }^{44}$ Indeed, subsequent tribunals have reasoned that, because importation of standards of treatment is permitted, there is no reason to preclude importation of dispute resolution provisions. ${ }^{85}$ At the other end of the spectrum, some tribunals have reasoned that, even though importing standards of treatment is uncontroversial, importing dispute resolution provisions is different in nature and impermissible. ${ }^{86}$ Although these two sets of pronouncements led to diametrically opposite conclusions, they both started from the presumption that the use of MFN clauses to import standards of treatment is unproblematic. ${ }^{87}$

${ }^{82}$ Salini Costruttori S.p.A. v. Hashemite Kingdom of Jordan, ICSID Case No. ARB/02/13, Decision on Jurisdiction, paras. 102-19 (Nov. 15, 2004) [hereinafter Salini].

${ }^{83} I d$., para. 112 (emphasis added).

${ }^{84}$ Rivas, supra note 5, at 436.

85 See, e.g., RosInvestCo UK Ltd. v. The Russian Federation, SCC Case No. V079/2005, Award on Jurisdiction, paras. 131-32 (Oct. 2007) (stating that, in light of the generally accepted application of MFN clauses to substantive provisions, the clause arguably applied "even more to 'only' procedural protection," that importation of treaty provisions is the "the very character and intention" of MFN clauses, and that "[i]f this effect is generally accepted in the context of substantive protection, the Tribunal sees no reason not to accept it in the context of procedural clauses such as arbitration clauses") [hereinafter RosInvest]; Suez, Sociedad General de Aguas de Barcelona, S.A., and Vivendi Universal, S.A. v. The Argentine Republic, ICSID Case No. ARB/03/19, Decision on Jurisdiction, para. 59 (Aug. 3, 2006) ("[T]he Tribunal finds no basis for distinguishing dispute settlement matters from any other matters covered by a bilateral investment treaty.”) [hereinafter Suez]; Austrian Airlines v. The Slovak Republic, UNCITRAL, Final Award, para. 124 (Oct. 9, 2009) (finding "no conceptual reason why an MFN clause should be limited to substantive guarantees"); Renta 4 S.V.S.A. et al. v. The Russian Federation, SCC Case No. V24/2007 [hereinafter Renta 4], Separate Opinion of Charles Brower, para. 10 (Mar. 20, 2009) ("I see no reason why an issue of the incorporation of broader consent to arbitration under the host State's third-country investment treaties should be treated differently from the consistently accepted application of MFN clauses to substantive standards of treatment. . ..”).

${ }^{86}$ Plama, supra note 46, para. 209 ("It is one thing to add to the treatment provided in one treaty more favorable treatment provided elsewhere. It is quite another thing to replace a procedure specifically negotiated by parties with an entirely different mechanism."); see also Telenor Mobile Communications A.S. v. The Republic of Hungary, ICSID Case No. ARB/04/15, Award, para. 92 (Sept. 13, 2006) (finding that the ordinary meaning of the clause at issue "is that the investor's substantive rights in respect of the investments are to be treated no less favourably than under a BIT between the host State and a third State, and there is no warrant for construing the above phrase as importing procedural rights as well") (emphasis in original) [hereinafter Telenor]; Daimler Financial Services AG v. Argentine Republic, ICSID Case No. ARB/05/1, Award, para. 219 \& n. 376 (Aug. 22, 2012) (noting the "lively debate" among public international lawyers over whether the term "treatment" should be understood to comprise "only 'substantive' treaty protections, or whether it may also include 'procedural' ones") [hereinafter Daimler].

${ }^{87}$ For views on the role of presumptions in this area, see Kinnear, supra note 40, at 48 ("Whatever one's philosophical leanings are, it is clear that the presumptions and public policy exceptions in cases like Maffezini and Plama are not found in the express language of the treaties being interpreted in those cases."); Schill, supra note 5, at 549 (arguing that "MFN clauses, their wording permitting, need to be understood broadly as multilateralizing not only substantive investor rights and applying to admissibility-related issues, but equally multilateralizing arbitral jurisdiction by incorporating the host State's broader consent from its third-country investment treaties"). 
Thus, one of the striking features of the post-Maffezini debate is the adoption by both sides of a top-down approach to MFN clauses. This is particularly clear in the expressed view of tribunals and commentators that the Ambatielos case provides a precedent for importing procedural standards via MFN, ${ }^{88}$ or that it supports only the importation of "substantive provisions." 89 Tribunals and commentators rarely grapple with the differences in text, context, and purpose between the MFN provisions in the investment treaties they are applying and the clauses in Ambatielos and other earlier cases, ${ }^{90}$ even though those differences are substantial. ${ }^{91}$ This indifference to variation across texts may seem unusual for a debate that is all about the interpretation of treaty clauses, but it is fully consistent with the top-down view that MFN clauses by default share a common nature and function.

\section{B. The Application of the Conventional Wisdom: The Standards of Treatment Cases}

The post-Maffezini debate has thus given rise to a widely shared view that the essential function of MFN clauses in investment treaties is to import treaty standards. This view, consistent with the top-down approach to interpretation, has sometimes been applied without regard to variations in treaty language. Indeed, of the twelve published decisions we have identified that allowed importation of standards of treatment, ${ }^{92}$ most fail to engage with

${ }^{88}$ Maffezini, supra note 1, paras. 48-53; see also Schill, Adjudicatory Authority, supra note 50, at 369 \& n. 61 (arguing that the Ambatielos case imposes no "strict separation" between substantive and procedural provisions).

89 See, e.g., Plama, supra note 46, paras. 215, 225 (noting that the ruling in Ambatielos "relates to provisions concerning substantive protection in the sense of denial of justice in the domestic courts. It does not relate to the import of dispute resolution provisions of another treaty into the basic treaty" and referring to the same conclusions in Salini v. Jordan); Salini, supra note 82, para. 112; Douglas, Off the Rails, supra note 2, at 102.

90 See, e.g., Maffezini, supra note 1, paras. 48-51 (addressing the Ambatielos decision but not the underlying treaty text in that case); Plama, supra note 46, paras. 215, 217 (similar); Salini, supra note 82, para. 117 (discussing only the final clause of the MFN provision, which provides "that the trade and navigation of each country be placed, in all respects, by the other on the footing of the most-favoured-nation" (emphasis in the Salini decision))

91 See supra Part I.B.

92 MTD Equity Sdn. Bhd. and MTD Chile S.A. v. Republic of Chile, ICSID Case No. ARB/01/7, Award (May 25, 2004) [hereinafter MTD]; Rumeli Telekom A.S. and Telsim Mobil Telekomunikasyon Hizmetleri A.S. v. Republic of Kazakhstan, ICSID Case No. ARB/05/16, Award (July 29, 2008) [hereinafter Rumeli]; L.E.S.I S.p.A. and ASTALDI S.p.A. v. République algérienne démocratique et populaire, ICSID Case No. ARB/05/3, Award (Nov. 12, 2008) [hereinafter LESI]; Bayindir Insaat Turizm Ticaret Ve Sanayi A.S. v. Islamic Republic of Pakistan, ICSID Case No. ARB/03/29, Award (Aug. 27, 2009) [hereinafter Bayindir]; ATA Construction, Industrial and Trading Company v. The Hashemite Kingdom of Jordan, ICSID Case No. ARB/08/2, Award (May 18, 2010) [hereinafter ATA]; Sergei Paushok, CJSC Golden East Company and CJSC Vostokneftegaz Company v. The Government of Mongolia, UNCITRAL, Award on Jurisdiction and Liability (Apr. 28, 2011) [hereinafter Paushok]; White Industries Australia Limited v. The Republic of India, UNCITRAL, Final Award (Nov. 30, 2011) [hereinafter White Industries]; EDF International S.A., SAUR International S.A. and León Participaciones Argentinas S.A. v. Argentine Republic, ICSID Case No. ARB/03/23, Award (June 11, 2012) [hereinafter EDFI]; Mr. Franck Charles Arif v. Republic of Moldova, ICSID Case No. ARB/11/23, Award (Apr. 8, 2013) [hereinafter Arif]; OAO Tatneft v. Ukraine, UNCITRAL, Award on the Merits (July 29, 2014) [hereinafter Tatneft; Hesham Talaat M. Al-Warraq v. The Republic of Indonesia, UNCITRAL, Final Award (Dec. 15, 2014) [hereinafter Al-Warraq]; Teinver S.A., Transportes de Cercanías S.A. and Autobuses Urbanos del Sur S.A. v. The Argentine Republic, ICSID Case No. ARB/09/1, Award (July 21, 2017) [hereinafter Teinver]. Another study identified fifty cases involving claims for "substantive" MFN treatment. See Caron \& Shirlow, supra note 13, n. 8. That study covered not only decisions ruling on MFN importation of standards of treatment, which is the focus of this article, but also a number of other uses of MFN. These included decisions involving claims of breach of MFN clauses based on allegedly discriminatory state measures, and decisions involving attempts to overcome unfavorable treaty provisions, both of which are discussed above in Part I.A. That study also included cases in which the tribunal did not find it necessary under the circumstances of the case to decide on the claimant's attempt to import a standard of treatment via MFN. See, e.g., Occidental Exploration and Production Company v. The Republic of 
the actual text of the MFN provision. The cases in this area have built on each other, and interacted with the dispute settlement cases, in a manner that perpetuates the conventional view regarding importation of standards of treatment. And the cases that do address the treaty text have generally done so in a manner that reaffirms the conventional view, presuming that importation of standards of treatment is permissible unless otherwise expressly excluded.

In the following discussion, we trace in roughly chronological fashion the development of this jurisprudence through four main cases-MTD v. Chile, Bayindir v. Pakistan, White Industries $v$. India, and Al-Warraq v. Indonesia - noting other relevant cases along the way.

\section{MTD v. Chile}

The first published investment treaty decision in which an MFN clause was used to import substantive standards of treatment was the 2004 award in MTD v. Chile. ${ }^{93}$ In that case, the claimant relied on the MFN clause to import provisions from two third-party treaties relating to the observance of undertakings and to the grant of permits. ${ }^{94}$ The MFN and the FET provisions were both contained in the same clause, which stated:

Investments made by investors of either Contracting Party in the territory of the other Contracting Party shall receive treatment which is fair and equitable, and not less favourable than that accorded to investments made by investors of any third State. ${ }^{95}$

Chile did not object to the claimant's importation argument, but the tribunal nonetheless decided to "satisfy itself" that the MFN clause could be used in this way. ${ }^{96}$ The tribunal framed the issue as "whether the provisions of the Croatia BIT and the Denmark BIT . . can be considered to be part of fair and equitable treatment." 97 In a single paragraph, the tribunal answered this question in the affirmative, stating that importation of the requested standards was "in consonance" with the FET standard as interpreted "in the manner most conducive to fulfill the objective of the BIT to protect investments and create conditions favorable to

Ecuador, LCIA Case No. UN 3467, Award, para. 178 (July 1, 2004) (finding it unnecessary to rule on an attempt to import a national treatment clause because the tribunal had already found a breach of the national treatment clause in the basic treaty); Pantechniki S.A. Contractors \& Engineers v. The Republic of Albania, ICSID Case No. ARB/07/21, Award, para. 86 (July 30, 2009) (noting that Albania had "avoided debate" by conceding that the claimant could rely on fair and equitable treatment (FET) "irrespective of the presence or absence of an MFN clause”); Impregilo S.p.A. v. Islamic Republic of Pakistan, ICSID Case No. ARB/03/3, Decision on Jurisdiction, para. 223 (Apr. 22, 2005) (stating that a claim based on an "umbrella" clause would fail even assuming arguendo that the claimant could invoke such a clause via MFN); Waguih Elie George Siag and Clorinda Vecchi v. The Arab Republic of Egypt, ICSID Case No. ARB/05/15, Award, para. 464 (June 1, 2009) (having decided in the claimants' favor on expropriation and FET, the tribunal found that "nothing would be added to Claimants' claim by the invocation of the most favoured nation doctrine and the 'umbrella clause' of the Egypt Greece BIT"). These decisions do not address the justification for using MFN provisions to import standards of treatment, and we therefore do not discuss them in this Part.

93 E.g., Yas Banifatemi, The Emerging Jurisprudence on the Most-Favoured-Nation Treatment in Investment Arbitration, in Investment Treaty Law: Current Issues III, at 241, 248 (Andrea K. Bjorklund, Ian A. Laird \& Sergey Ripinsky eds., 2009) (stating that "[t]he only tribunal" to give effect to FET via an MFN clause was the MTD tribunal) [hereinafter Banifatemi]. But see the earlier dictum in the Pope \& Talbot case, discussed infra Part IV.A.

${ }^{94}$ MTD, supra note 92, para. 103.

95 See id., para. 101 (quoting Art. 3(1) of the Chile-Malaysia BIT).

${ }^{96}$ Id., para. 100; see also Teinver, supra note 92, n. 1089 (stating that the respondent's lack of objection in MTD was "worth noting").

${ }^{97}$ MTD, supra note 92, para. 103. 
investments."98 That puzzling interpretation came under scrutiny when Chile applied for annulment of the award, with Chile arguing that the tribunal's reasoning on the point was "incomprehensible." 99 The ad hoc committee agreed with Chile that the tribunal's reasoning was flawed, noting that the tribunal "appears to confuse" FET and MFN. ${ }^{100}$

Despite the perfunctory analysis and apparent confusion in that case, commentators and practitioners writing in the years that followed frequently suggested, citing $M T D$, that importation of substantive standards via MFN was unproblematic. ${ }^{101}$ This perception was reinforced by the continued dispute over incorporation via MFN of more favorable jurisdictional provisions, which appeared to be the locus of all the MFN-related action.

The few tribunals in the years after $M T D$ to address importation of substantive provisions did so with little analysis, or with none at all. In the LESI case, for instance, the tribunal permitted importation of an FET clause based on perfunctory analysis of the term "treatment" in the applicable MFN provision, finding that the term extended to "all aspects of the "treatment' of foreign investments, including their promotion and their protection." 102 In another series of cases, tribunals limited their analysis to noting that the respondents' counsel did not object to the use of MFN to import standards of treatment. ${ }^{103}$

\section{Bayindir v. Pakistan}

The next decision after $M T D$ to address at any length the importation of substantive standards, the 2009 Bayindir v. Pakistan award, reflects the influence of the growing conventional

98 Id., para. 104

${ }^{99}$ MTD Equity Sdn. Bhd. and MTD Chile S.A. v. Republic of Chile, ICSID Case No. ARB/01/7, Decision on Annulment, para. 63 (Mar. 21, 2007).

${ }^{100} \mathrm{Id}$. However, the committee found that this error had no consequence, since the tribunal had rejected the claims based on the provisions from third-party treaties invoked by the claimant. Id., para. 64. The ad hoc committee also offered its own view of the MFN clause, which appeared to sweep even more broadly. See id. (stating that the MFN clause was meant to "unconditionally" permit importation of "any more favourable treatment extended to third State investments").

101 See, e.g., Banifatemi, supra note 93, at 246-47 (finding no "conceptual difficulties in situations where the better treatment sought by the investor relates to the classic substantive protection accorded by the host State respectively in the basic treaty and in third-party treaties"); Dumberry, Shopping For a Better Deal, supra note 4, at 13 (" $[\mathrm{O}]$ ne can only approve the reasoning of the $[M T D]$ Tribunal on the importation of the FET clause in this case."); Panel Discussion, MFN Treatment - What Are Its Limits in the Investment Context?, in 1 INVESTMENT Treaty Arbitration and International Law 247, 248 (Todd J. Grierson Weiler ed., 2008) (Noah Rubins: "[T]here is relatively little debate today as to whether one can fill in the blanks of substantive protections in an investment protection treaty by reference to other investment treaties that the host State has also entered into with third States. The typical example and the one that was tried and passed off without any objection by the host State was in $M T[D] v$. Chile, where the applicable Chilean treaty had no umbrella clause, and they wanted to use one. The claimant simply stated: well, there is an MFN clause, and Chile signed all kinds of BITs that have umbrella clauses, therefore we're going to import that.").

102 See LESI, supra note 92, para. 150 (authors' translation).

${ }^{103}$ Rumeli, supra note 92, para. 575; Tatneft, supra note 92, para. 365; see also ATA, supra note 92, n. 16 (dealing with the MFN provision in a footnote, which suggests (although the respondent's position is not recorded) that there was no or little contest as to this use of MFN). It is not clear that the MFN provisions at issue in those cases would have permitted importation, had the respondents contested their use in this manner. Indeed, the applicable MFN clauses in Rumeli and ATA (and in Bayindir discussed below) were identical to the MFN clause at issue in İckale, where the tribunal rejected importation on the basis of the clause's text. See infra Part III; see also Dumberry, Importation, supra note 5, at 124 (finding the absence of objection in Rumeli "quite surprising"); Jarrod Hepburn, Analysis: In a Recent MFN Clause Interpretation, Arbitrators Diverge from More Generous Approach Taken by Certain Earlier Tribunals, InVESTMENT ARB. Rep. (Mar. 15, 2016) (noting the similarity among the relevant clauses). 
wisdom. By that time, numerous decisions had been rendered on the issue of importation of dispute settlement provisions through MFN, crystallizing the procedure/substance dichotomy. ${ }^{104}$

In Bayindir, the claimant invoked the MFN clause in the Turkey-Pakistan BIT for two distinct purposes: (1) to claim that Pakistan's allegedly more favorable treatment of other contractors involved in the same economic sector as the claimant breached the MFN clause- the first category of MFN uses referred to earlier; ${ }^{105}$ and (2) to import an FET clause that was absent from the basic treaty. ${ }^{106}$ In a demonstration of the reflexive approach taken by tribunals when addressing importation of substantive standards, the tribunal applied two very different interpretive methods for each of the claimant's MFN claims.

In addressing the first of these two MFN claims, which was based on the actual conduct of Pakistan toward other contractors, the tribunal closely analyzed the terms of the MFN clause and grounded its decision in those terms, in line with a bottom-up approach. The MFN clause in the Turkey-Pakistan BIT is a common formulation, providing that each party shall accord treatment to established investments that is "no less favourable than that accorded in similar situations ... to investments of investors of any third country." 107 The tribunal accordingly stated that it "must first assess whether Bayindir was in a 'similar situation' to that of other investors"; this was a "fact specific" inquiry, which "must be examined at the level of the contractual terms and circumstances." 108 The tribunal went on to reject this MFN claim, finding that it was in "no position to proceed to any meaningful comparison between the different situations at issue" because it did not have "sufficiently specific data on the terms and the performance of the different contracts involved." 109 The claimant, therefore, had failed to demonstrate one of the "necessary requirements" of MFN. ${ }^{110}$

When it turned to the question of importation of an FET provision via MFN, however, the Bayindir tribunal departed from this close textual analysis. The tribunal asserted, without discussion, that the "ordinary meaning of the words" of the MFN clause "show that the parties to the Treaty did not intend to exclude the importation of a more favourable substantive standard of treatment," 111 and supported its conclusion with a reference to the MTD case. ${ }^{112}$ The

\footnotetext{
${ }^{104}$ See, in addition to Maffezini and Salini, Siemens A.G. v. The Argentine Republic, ICSID Case No. ARB/02/8, Decision on Jurisdiction (Aug. 3, 2004); Plama, supra note 46; Gas Natural SDG, S.A. v. The Argentine Republic, ICSID Case No. ARB/03/10, Decision of the Tribunal on Preliminary Questions on Jurisdiction (June 17, 2005); Berschader, supra note 4; Suez, supra note 85; Telefónica S.A. v. The Argentine Republic, ICSID Case No. ARB/03/20, Decision on Jurisdiction (May 25, 2006); National Grid Plcv. The Argentine Republic, UNCITRAL, Decision of the Tribunal on Objections to Jurisdiction (June 20, 2006); Telenor, supra note 86; RosInvest, supra note 85; Wintershall Aktiengesellschaft v. Argentine Republic, ICSID Case No. ARB/04/14, Award (Dec. 8, 2008); Renta 4, supra note 85, Award (Mar. 20, 2009); Señor Tza Yap Shum v. The Republic of Peru, ICSID Case No. ARB/07/6, Decision on Jurisdiction and Competence (June 19, 2009).

105 See supra Part I.A.

${ }^{106}$ At the jurisdictional phase, the tribunal had allowed that each of these uses of MFN was prima facie permissible under the BIT. Bayindir Insaat Turizm Ticaret ve Sanayi A.S. v. Islamic Republic of Pakistan, ICSID Case No. ARB/03/29, Decision on Jurisdiction, paras. 201-32 (Nov. 14, 2005).

${ }^{107}$ Bayindir, supra note 92, para. 386. The full clause is combined with a national treatment obligation, and further provides that the better of national treatment and MFN treatment shall apply.

${ }^{108}$ Id., paras. 389, 416.

${ }^{109} I d$., para. 417.

${ }^{110}$ Id., para. 420.

${ }^{111} I d$., para. 157.

${ }^{112} I d$., para. 158.
} 
tribunal appeared to suggest that importation was further supported by the absence of any reference to this practice in the express limitations on the MFN clause, which consisted only of widely used exceptions for taxation and treatment arising out of participation in a customs union. ${ }^{113}$

This analysis reflects the application of the "sticky default," conventional approach to MFN. Although the tribunal referred to the "ordinary meaning" of the text, it did not attempt to follow the kind of textual analysis that it applied to the claimant's disparate-treatment claim. ${ }^{114}$ For example, the tribunal made no visible effort to apply the "in similar situations" element of the MFN clause in the context of the incorporation claim, which the tribunal had elsewhere deemed a "necessary requirement" that entailed a "fact specific" inquiry. ${ }^{115}$ Instead, the tribunal appeared to turn to the text only to satisfy itself that there was no express language excluding the possibility of importation. Thus, the tribunal appears to have presumed that the MFN clause was intended to permit importation in the first place.

\section{White Industries v. India}

The White Industries case, decided two years after Bayindir, reflects the consolidation of this approach. The claimant in that case sought to incorporate an "effective means" clause from a third-party treaty via the MFN clause in the India-Australia BIT, which provided that a party "shall at all times treat investments in its own territory on a basis no less favourable than that accorded to investments or investors of any third country." 116 India resisted this attempt, arguing, inter alia, that to do so would subvert "the carefully negotiated balance of the BIT." 117

The tribunal's rejection of India's argument reflects just how entrenched the conventional view of MFN had become. The award in White Industries provided no analysis of the particular terms of the applicable MFN clause. ${ }^{118}$ Instead, the tribunal relied upon the distinction between procedure and substance that grew out of the post-Maffezini cases, and it married

${ }^{113}$ See id., paras. 156-57. The tribunal also distinguished the MFN cases involving procedural provisions, stating puzzlingly that "the ejusdem generis principle that is sometimes viewed as a bar to the operation of the MFN clause with respect to procedural rights does not come into play here and the words of the Treaty are clear." Id., para. 159. That statement is confusing because the ejusdem generis principle concerns the interpretation of MFN clauses in general, not just the importation of "procedural" provisions. See supra Part I.B.

${ }^{114}$ Compare Bayindir, supra note 92, paras. 153-60, with id., paras. 386-90, 415-23. In a similar vein, in a case concerning the use of an MFN clause to import dispute settlement provisions, the tribunal expressly distinguished between a "claim for relief for an alleged breach of the MFN clause," for which "a claimant must normally establish the existence of a comparator and then demonstrate that such comparator has received better treatment," and the use of the MFN clause to import standards of treatment, for which the relevant comparison is "between the standard of treatment guaranteed to a group of investors by one treaty and the standard of treatment guaranteed to another group of investors by another treaty." European American Investment Bank AG v. The Slovak Republic, UNCITRAL, PCA Case No. 2010-17, Award on Jurisdiction, para. 435 (Oct. 22, 2012). The justification for the tribunal's dual approach to various types of claims based on the same MFN clause cannot be easily discerned from the text of the applicable clause, which stated: "Each Contracting Party shall accord to investors of the other Contracting Party and to their investments treatment that is no less favourable than that which it accords to its own investors or to investors of any third States and their investments." Id., para. 407.

${ }^{115}$ As discussed below, the İckale tribunal later relied on this same element to reject importation. See infra Part III.

${ }^{116}$ White Industries, supra note 92, paras. 11.1.1-.4.

${ }^{117}$ Id., paras. 11.2.1-.2 \& n. 73 (quoting Campbell McLachlan, Laurence Shore \& Matthew Weiniger, International Investment Arbitration: Substantive Principles (2007)).

${ }^{118}$ See White Industries, supra note 92, paras. 11.2.1-.9. 
this distinction to a seemingly inflexible top-down conception of what the MFN clause was designed to do. In a passage remarkable for its breadth, the tribunal stated:

Here, White is not seeking to put in issue the dispute resolution provisions of the BIT, but is instead availing itself of the right to rely on more favourable substantive provisions in the third-party treaty.

This does not "subvert" the negotiated balance of the BIT. Instead, it achieves exactly the result which the parties intended by the incorporation in the BIT of an MFN clause. ${ }^{119}$

In the absence of any express analysis of the particular MFN clause at issue, the tribunal appears to have determined what the parties "intended by the incorporation . . . of an MFN clause" by applying a presumption that all parties mean the same thing when they write MFN clauses into their treaties, regardless of the specific wording. ${ }^{120}$

Following White Industries, two other tribunals appeared to apply a similar presumption with respect to the importation of substantive standards via MFN. In EDF International v. Argentina, the tribunal permitted importation of an "umbrella" clause via an MFN provision that referred to "treatment" accorded by the state "[w]ithin its territory and in its maritime zone," 121 without explaining how the presence of an "umbrella" clause in another treaty constituted such treatment. ${ }^{122}$ The tribunal stated that the MFN clause "by its terms, incorporates some provisions from other conventions" and that " $[\mathrm{t}]_{\mathrm{o}}$ interpret the BIT otherwise would effectively read the MFN language out of the treaty." 123 In Arif $v$. Moldova, the tribunal likewise allowed importation of an "umbrella" clause via MFN, referring to the then widely accepted distinction between MFN importation of procedural and substantive

119 Id., paras. 11.2.3-.4.

${ }^{120}$ Id., para. 11.2.4. For a criticism, see Ishikawa, supra note 16, at 129, 144 (arguing that the White Industries tribunal "should have approached the MFN issue as a matter of treaty interpretation, rather than relying solely on the substantive/procedural dichotomy").

121 The text of the MFN clause at issue is reproduced in EDFI, supra note 92, para. 207:

Within its territory and in its maritime zone, each Contracting Party shall provide to the investors of the other Party, with respect to their investments and activities associated with such investments, a treatment no less favorable than that accorded to its own investors or the treatment accorded to investors of the most favored Nation if the latter is more advantageous. For the same reason, the nationals of either of the Contracting Parties authorized to work in the territory and in the maritime zone of the other Contracting Party shall be able to enjoy suitable terms for the conduct of their professional activities.

122 See id., paras. 921-37. A subsequent ad hoc committee decision found that it was not annullable error for the tribunal to have considered the term "treatment" in an MFN clause to encompass a commitment in a treaty to honor commitments undertaken with respect to investments. See EDF International S.A., SAUR International S.A. and León Participaciones Argentinas S.A. v. Argentine Republic, ICSID Case No. ARB/03/23 (Annulment Proceeding), Decision, paras. 237-39 (Feb. 5, 2016) ("If German investors in Argentina have the benefit of a treaty provision requiring the Host State to honour commitments undertaken (or entered into) in relation to their investment, then they are being accorded a form of treatment which is not expressly granted to French investors by the Argentina-France BIT. That situation falls squarely within the terms of the MFN clause. Even if Argentina is right in arguing that MFN clauses should be subjected to an ejusdem generis limitation-as to which, it is unnecessary for the Committee to comment- the umbrella clause is part of the same genus of provisions on substantive protection of investments as the fair and equitable treatment clause and other similar provisions which feature in the Argentina-France BIT.").

${ }^{123}$ EDFI, supra note 92, para. 933. Note, however, that the use of MFN to remedy nationality-based discrimination would not necessarily be "read out of the treaty" by the contrary interpretation. See supra Part I.A. 
provisions. ${ }^{124}$ The tribunal simply noted that MFN clauses apply to "substantive obligations" (this was undisputed), that the clause in this case is "broadly drafted," and that an umbrella clause is "substantive" in nature. ${ }^{125}$

\section{Al-Warraq v. Indonesia}

A similar presumption appears to be at work in the Al-Warraq $v$. Indonesia award. ${ }^{126}$ The claimant sought to use the MFN clause in the Organization of the Islamic Conference Agreement on Investment (OIC Agreement) to attract an FET provision from the U.K.Indonesia BIT. ${ }^{127}$ The MFN clause of that treaty provides:

The Investors of any contracting party shall enjoy, within the context of economic activity in which they have employed their investments in the territories of another contracting party, a treatment not less favourable than the treatment accorded to investors belonging to another State not party to this Agreement, in the context of that activity and in respect of rights and privileges accorded to those investors. ${ }^{128}$

This clause is notable because it is limited to treatment "within the context of economic activity in which [investors] have employed their investments"- a limitation that does not often appear in these precise terms in other MFN clauses. The respondent argued that this language made clear that the MFN clause applied only to discrimination among nationalities in the context of a particular economic activity, and did not provide "carte blanche to selectively import obligations from the universe of treaties signed by Indonesia." 129

The tribunal rejected this argument. It first noted that "a number of contemporary arbitral decisions" had recognized the ability of MFN clauses to import third-treaty FET standards. ${ }^{130}$ The tribunal then stated its view "that the MFN clause applies to import other clauses as long as the ejusdem generis rule applies." 131 The ejusdem generis principle was satisfied in this instance, the tribunal reasoned, because both the OIC Agreement and the U.KIndonesia BIT shared the same purpose of protecting foreign investment, as reflected in each treaty's preamble. ${ }^{132}$ Once satisfied in principle that the treaty allowed for MFN importation, the tribunal dispensed with the clause's "economic activity" limitation, reasoning that, since both the basic and target treaties governed investments in the banking sector, this language was not an obstacle to importation. ${ }^{133}$ This analysis is in line with a strong presumption that MFN clauses are designed to import standards of treatment unless specific treaty text expresses a clear intent to specifically restrict that practice.

${ }^{124}$ Arif, supra note 92, paras. 395-96.

${ }^{125} \mathrm{Id}$.

126 See Al-Warraq, supra note 92, paras. 540-55.

${ }^{127}$ Id., para. 540. There is no FET clause in the Organization of the Islamic Conference Agreement on Investment.

${ }^{128} I d$., para. 381.

${ }^{129}$ Id., para. 397.

${ }^{130} \mathrm{Id}$., para. 541.

${ }^{131}$ Id., para. 551.

${ }^{132} I d$., paras. 548-51.

${ }^{133} I d$., para. 552. 
The tribunal's approach, however, is not necessarily in line with the interpretive tools that the tribunal purported to apply, which might have counseled a bottom-up, rather than topdown, approach. As originally formulated, the ejusdem generis principle, which the Al-Warraq tribunal applied, is not satisfied simply by noting that the third-party treaty is of the same kind as the basic treaty. Instead, as discussed earlier, the principle of ejusdem generis focuses on whether the benefit invoked is of the same kind as that contemplated in the MFN clause. ${ }^{134}$ Applied in this way, the ejusdem generis principle directs the interpreter not to the broad purposes of the basic and target treaties, but rather to the specific terms of the MFN clause at issue. This approach would have led the Al-Warraq tribunal to grapple with the "economic activity" language before reaching a conclusion in principle on the ability of the MFN clause to import other treaty standards. By tinkering with the formulation of the ejusdem generis principle, the $A l$-Warraq tribunal effectively converted that principle into a method for harmonizing interpretations and minimizing differences across MFN clauses.

It should be noted that not all decisions apply an entirely top-down approach to MFN treaties, and there may be a growing counter-trend toward recognizing at least some limitations on MFN importation, even where such limitations are not stated as an express carveout. For example, in Paushok, the tribunal allowed importation of an FET provision because the scope of the MFN clause was defined by reference to a clause in the basic treaty referring to FET, ${ }^{135}$ but it rejected an attempt to import "completely new substantive rights" unrelated to FET. ${ }^{136}$ And in Teinver, the tribunal found that an MFN clause applying to "all matters governed by this Agreement" covered "the various rights or forms of protection contained in the individual provisions of the Treaty." 137 The tribunal allowed importation of a "full protection

${ }^{134}$ See supra Part I.B. (discussing the expression of the ejusdem generis principle in Ambatielos); see also ILC 1978 Draft Articles, supra note 25, at 21 (referring to " $\mathrm{t}$ ] he ejusdem generis rule, according to which no other rights can be claimed under a most-favoured-nation clause than those falling within the limits of the subject-matter of the clause ..."); id. at 30 ("The essence of the rule is that the beneficiary of a most-favoured-nation clause cannot claim from the granting State advantages of a kind other than that stipulated in the clause."); id. Art. 9(1) (stating the principle); ILC 2015 Report, supra note 17, paras. 15, 214 ("The central interpretative issue in respect of the MFN clauses relates to the scope of the clause and the application of the ejusdem generis principle. That is, the scope and nature of the benefit that can be obtained under an MFN provision depends on the interpretation of the MFN provision itself."); Paushok, supra note 92, para. 565 (referring to the Ambatielos case for the proposition that "the most-favored-nation clause can only attract matters belonging to the same category of subject as that to which the clause itself relates"); N. STEPHAN Kinsella \& NoAH D. RUbins, InTERnATIONAL InVESTMENT, Political Risk, and Dispute Resolution 228 (2005) ("Variations in the express scope of MFN clause application are particularly important, given that investors can only acquire by way of an MFN provision those rights 'which fall within the subject matter' of the clause."'); Ishikawa, supra note 16, at 134-35 (arguing that "there is no rule that all matters concerning substantive protection of investors/investments automatically fall into 'the subject-matter[']" of the clause and that " $[\mathrm{t}]$ he ejusdem generis rule equally applies to matters concerning substantive protection of investors/investments, and therefore tribunals facing the issue of the applicability of an MFN clause in this context need to examine whether or not such matters fall in the same category of subject to which the clause relates").

${ }^{135}$ The MFN clause stated: "The treatment mentioned under paragraph 1 of this Article, shall not be less favorable than treatment accorded to investments and activities associated with investments of its own investors or investors of any third State." Paushok, supra note 92, paras. 562-63. "Paragraph 1" referred to a provision stating: "Each Contracting Party shall, in its territory, accord investments of investors of the other Contracting Party and activities associated with investments fair and equitable treatment excluding the application of measures that might impair the operation and disposal with investments." Id.

${ }^{136} I d$., paras. 570-73. In setting the stage for its MFN analysis, the tribunal noted that prior tribunals had diverged on the issue of importation of dispute settlement provisions but noted that "this issue need not be addressed in the present case, the question relating simply to the import of substantive rights." Id., paras. 564-65.

137 Teinver, supra note 92, para. 884. 
and security" clause because the basic treaty already contained a clause relating to the "protection" of investments, but rejected an attempt to import an "umbrella" clause given the absence of such a clause in any form in the basic treaty. ${ }^{138}$ Nevertheless, these decisions did not expressly challenge the conventional view that, as a matter of principle, MFN clauses are designed to import standards of treatment from third-party treaties.

In sum, as demonstrated in this Part, most tribunals have relied on a presumption concerning the use of MFN clauses to import standards of treatment. The MTD award, which was the first to adopt this practice, did not appear to provide a complete rationale for MFN importation, either in terms of the specific clause at issue or more generally. In the years that followed, tribunals generally rendered decisions based on simplified distinctions between "procedural" and "substantive" provisions, or on generic conceptions of what "the" MFN clause is for, at the expense of any sustained consideration of the treaty text.

\section{III. İÇKALE V. TuRKMENistan: A Turn to the BotTom-Up Approach?}

The award in $\dot{I}_{c ̧} k a l e$, which for the first time refused to import any substantive standard of treatment via an MFN clause on the ground that the clause did not permit such importation, provides an opportunity to rethink the prevailing approach to MFN clauses in investment treaties.

This case arose under the Turkey-Turkmenistan BIT, and concerned alleged state conduct visà-vis several construction contracts concluded between the claimant and various state entities and state-owned companies. ${ }^{139}$ Most of the claimant's arguments depended on invoking a minimum standard of investment protection, such as FET or FPS, or an "umbrella" clause, all of which were absent from the Turkey-Turkmenistan BIT. ${ }^{140}$ The substantive protections in the TurkeyTurkmenistan BIT concern only expropriation and national and MFN treatment, along with provisions relating to entry and presence in the country, and free transfers of funds. ${ }^{141}$ The national and MFN treatment obligations in that treaty are phrased in familiar terms:

Each Party shall accord to these investments, once established, treatment no less favourable than that accorded in similar situations to investments of its investors or to investors of any third country, whichever is the most favourable. ${ }^{142}$

The claimant sought to use this provision as a vehicle for importing other standards of treatment from treaties concluded between Turkmenistan and third parties. ${ }^{143}$ The claimant invoked the prevailing presumption on MFN importation, relying on some of the tribunal

${ }^{138} I d$., paras. 866-96. In another case, the tribunal did not question the claimant's ability in principle to use the MFN clause to import standards of treatment, but it declined the claimant's attempt to create a "custom-made treaty provision" that did not appear in any third-party treaty and found that the provisions that the claimant was invoking would in any event not change the outcome under the circumstances of the case. Garanti Koza LLP v. Turkmenistan, ICSID Case No. ARB/11/20, Award, paras. 372-78, 393 (Dec. 19, 2016).

${ }^{139}$ İckale, supra note 20, paras. 113, 294-310.

140 See id., para. 148(ii)-(iv); Agreement Concerning the Reciprocal Promotion and Protection of Investments, Turk.-Turkm., May 2, 1992 [hereinafter Turkey-Turkmenistan BIT].

${ }^{141}$ See Turkey-Turmenistan BIT, supra note 140, Arts. II-IV.

${ }^{142}$ Id. Art. II.2. The phrase "these investments" refers to investments permitted into the host state's territory in accordance with the preceding Article II.1.

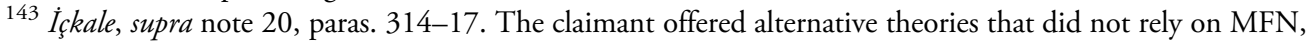
which were also rejected by the tribunal. See id., paras. 331, 333-41. 
decisions discussed earlier to argue that the term "treatment" in an MFN clause covers "at least the substantive protections provided to other foreign investors," and that such protections could thus be "imported from another bilateral investment treaty." ${ }^{44}$ Accordingly, the claimant asserted, it was entitled to invoke FET and other provisions contained in treaties concluded between Turkmenistan and Egypt, Bahrain, and the United Kingdom. ${ }^{145}$

Turkmenistan objected to the claimant's attempt to use the MFN provision to obtain the benefit of those standards of treatment. That clause, it argued, was a guarantee of nondiscrimination on the basis of nationality, analogous to a national treatment provision, and not a vehicle for importation. The provision, in the state's view, implied a comparative, factbased analysis, which considered, inter alia, whether the investors were similarly situated and "whether the treatment accorded to the host State's national or third State's national was in fact more favorable than that of the claimant." 146 In other words, Turkmenistan argued, the claimant invoking this provision must identify "an actual investment of an actual investor, in an actual 'similar situation,' who is actually receiving the allegedly more favorable treatment." 147

The tribunal sided with Turkmenistan, finding that the MFN provision "cannot be read, in good faith, to refer to standards of investment protection included in other investment treaties ...."148 Instead, the tribunal determined, the provision guaranteed non-discrimination, which "requires a comparison of the factual situation" of home-state investors and third-state investors. ${ }^{149}$ Because the claimant was not alleging that it received unfavorable treatment vis-à-vis similarly situated investors of third states, its effort to invoke the MFN provision was dismissed in its entirety.

The tribunal based this holding on a parsing of the treaty text. ${ }^{150}$ In particular, the tribunal determined that it was bound to give effect to the comparative language in the MFN provision, which limited the clause's application to cases in which at least two investors of differing nationality were "in similar situations." 151 This language limited the provision's application to differences in actual treatment among investors, rather than to mere theoretical differences created by the presence or absence of provisions in different treaties. The tribunal explained:

The standards of protection included in other investment treaties create legal rights for the investors concerned, which may be more favorable in the sense of being additional to the standards included in the basic treaty, but such differences between applicable legal standards cannot be said to amount to "treatment accorded in similar situations," without effectively denying any meaning to the terms "similar situations." Investors cannot be said to be in a "similar situation" merely because they have invested in a particular State; indeed, if the terms "in similar situations" were to be read to coincide with the territorial scope of application of the treaty, they would not be given any meaning and would effectively become

${ }^{144} I d$., para. 315.

${ }^{145} I d$., para. 314.

${ }^{146} I d$., para. 321 (alterations omitted).

${ }^{147} \mathrm{Id}$.

${ }^{148} I d$., para. 329.

${ }^{149}$ Id., paras. 328-29.

150 See id., para. 328 (applying Article 31 of the Vienna Convention).

151 Turkey-Turkmenistan BIT, supra note 140, Art. II.2. 
redundant .... Such a reading would not be consistent with the generally accepted rules of treaty interpretation, including the principle of effectiveness, or effet utile, which requires that each term of a treaty provision should be given meaning and effect. ${ }^{152}$

The tribunal's analysis is unique in its approach to the treaty text. Indeed, as we have noted above, MFN clauses drafted like the one at issue in $\dot{I}_{c} k a l e$ had already been relied upon to import standards of treatment in three prior cases - two of which apparently did not even draw the respondent's objection. ${ }^{153}$ And, unlike earlier cases where tribunals have denied importation of some standards based on the wording of the MFN clause (such as Paushok and Teinver), ${ }^{154}$ the $\dot{I}_{c} k$ ale award is the first to categorically state that a common formulation of the clause, by its very terms, does not permit the importation of standards of treatment.

There are arguably two ways to read the $\dot{I}_{c} k a l e$ award as it relates to the interpretation of MFN clauses. The first sees the award as a significant but perhaps predictable outgrowth of the trend in awards like Paushok and Teinver to temper the top-down approach to MFN clauses with a margin of sensitivity to detail and variation in texts. A second reading is that İckale reflects a readiness among some arbitrators to reconsider more fundamentally the topdown approach to MFN, bracketing broad notions as to the "essence" of MFN provisions and choosing instead to proceed with the goal of giving effect to the specific provisions of individual MFN clauses. Either reading would suggest a recalibration away from the conventional view of MFN and a greater role for bottom-up methods of interpretation.

\section{Resistance to the Use of MFN Clauses to Import Standards of Treatment}

Once we widen the lens beyond published investment arbitral awards, we find that the shift taken by the $\dot{I}_{c} k a l e$ tribunal toward a bottom-up approach dovetails with certain trends in the practice of states. In their capacities as litigants, non-disputing parties, and treaty drafters, states have in several instances taken steps to encourage sensitivity to the particular terms of MFN clauses, and to discourage the application of broad presumptions as to the nature and effect of "the" MFN clause. As we discuss in detail below, the three states parties to the NAFTA have repeatedly challenged the use of MFN to borrow standards of treatment from third-party treaties by emphasizing the particular terms of the MFN clause in the NAFTA. And the treaty practice in new investment agreements further indicates that some states have become uncomfortable with the liberal use of MFN to import substantive standards, and have sought to reassert control over the interpretation of basic terms in MFN clauses.

\section{A. The NAFTA Cases}

The states parties to the NAFTA—Canada, Mexico, and the United States—have opposed the importation of standards of treatment via MFN in the context of specific investment

152 İckale, supra note 20, para. 329.

153 See Bayindir, supra note 92, paras. 153-60; Rumeli, supra note 92, para. 575; ATA, supra note 92, n. 16. Subsequent to $\dot{I}_{c} k a l e$, yet another claimant reportedly managed to invoke an identically worded MFN clause to import standards of treatment. Alison Ross, Kazakhstan Ordered to Pay for Actions of Court Bailiffs, GLOBAL ARB. Rev. (Nov. 14, 2017).

${ }^{154}$ See, e.g., Paushok, supra note 92, paras. 562-73 (allowing importation of FET provisions but not other provisions); Teinver, supra note 92, paras. 866-96 (allowing importation of a full protection and security clause but not an umbrella clause). 
disputes over the interpretation of Article 1105 (Minimum Standard of Treatment). They have done so both in their pleadings and in submissions filed under NAFTA Article 1128, which permits non-disputing states to make submissions to an investment tribunal on questions of interpretation. Article 1128 of the NAFTA, allowing for submissions in arbitral proceedings by non-disputing parties, "helps ensure that the treaty is interpreted in a manner consistent with the views of all treaty parties, not just the claimant and respondent state." 155 It has been argued that the parties' concordant submissions and pleadings can evidence "subsequent practice," or "subsequent agreement," which must be taken into account pursuant to the ordinary rules of treaty interpretation. ${ }^{156}$

Article 1103 of the NAFTA supplies two similarly worded MFN provisions, one relating to "investors" and the other to "investments." As an example, the latter provision states, in full:

Each Party shall accord to investments of investors of another Party treatment no less favorable than that it accords, in like circumstances, to investments of investors of any other Party or of a non-Party with respect to the establishment, acquisition, expansion, management, conduct, operation, and sale or other disposition of investments. ${ }^{157}$

In several cases, claimants have sought to rely on this provision to borrow substantive standards of treatment in treaties between a NAFTA party and a third country. These efforts have met with resistance from the three states parties to the NAFTA, either in their role as respondent or as non-disputing parties in arbitration proceedings, and the claimants' attempts have never proven successful. ${ }^{158}$

155 Jeremy K. Sharpe, Possible Paradigmatic Changes in the Settlement of International Investment Disputes, 108 ASIL Proc. 193, 195-96 (2015); see also Martin Hunter \& Alexei Barbuk, NAFTA Chapter 11: Procedural Aspects of Non-disputing Party Interventions in Chapter 11 Arbitrations, 3 AsPer Rev. INT'L Bus. \& TRADE L. 151, 181 (2003) ("The message for Chapter 11 tribunals is therefore loud and clear. They should be sensitive to the vital interests of the non-disputing Parties in matters that may create persuasive if not binding authority on questions of interpretation of the NAFTA."); Jason Webb Yackee, Controlling the International Investment Law Agency, 53 Harv. INT'L L.J. 392, 434-37 (2012) (arguing for broader adoption of mechanisms that enable "informed and effective participation" by non-disputing states).

${ }^{156}$ E.g., Lee M. Caplan \& Jeremy K. Sharpe, United States, in Commentaries On Selected Model Investment Treaties 755, 833 (Chester Brown ed., 2013); Anthea Roberts, Power and Persuasion in Investment Treaty Interpretation: The Dual Roles of States, 104 AJIL 179, 219 (2010); TARCISIO GAZZINI, InTERPRETATION OF INTERNATIONAL INVESTMENT TREATIES 193-95 (2016).

${ }^{157}$ NAFTA, supra note 4, Art. 1103(2). Annex IV of the NAFTA contains three identically worded schedules of exceptions taken by each NAFTA party to MFN treatment. For example, the United States' exception reads, in part: "The United States takes an exception to Article 1103 for treatment accorded under all bilateral or multilateral international agreements in force or signed prior to the date of entry into force of this Agreement. For international agreements in force or signed after the date of entry into force of this Agreement, the United States takes an exception to Article 1103 for treatment accorded under those agreements involving: (a) aviation; (b) fisheries; (c) maritime matters, including salvage; or (d) telecommunications transport networks and telecommunications transport services (this exception does not apply to measures covered by Chapter Thirteen (Telecommunications) or the production, sale or licensing of radio or television programming)." Id., Annex IV. Annex IV has not been the subject of any NAFTA arbitral tribunal decision. Canada has argued that its schedule "simply takes an exception for treatment given, for example by way of regulatory measures, under a provision of a pre-NAFTA BIT" and that " $t$ ] his exception does not open the door to 'standard shopping' in all BITs post-NAFTA." Chemtura Corporation v. Government of Canada, UNCITRAL [hereinafter Chemtura], Canada's Rejoinder, para. 239 (July 10, 2009) [hereinafter Chemtura, Canada's Rejoinder].

${ }^{158}$ See Dumberry, MFN in NAFTA Cases, supra note 3, at 10, 14. 


\section{Pope \& Talbot v. Canada and Methanex v. United States}

The issue of whether Article 1103 can be used to import standards of treatment from thirdparty treaties arose relatively early in the history of NAFTA arbitration, in Pope \& Talbot v. Canada. In its 2001 award on liability, the tribunal referred to the MFN clause as evidence that Article 1105, on the minimum standard of treatment, supplied an "autonomous" standard rather than the standard of treatment under customary international law. ${ }^{159}$ If it were otherwise, the tribunal stated, then investors could "simply" turn to the MFN clause in NAFTA Article 1103 "for relief." 160 A few months later, the NAFTA Free Trade Commission (FTC), composed of the three states parties, issued a note of interpretation clarifying that Article 1105 prescribes the minimum standard of treatment of aliens under customary international law. ${ }^{161}$

Following an invitation by the tribunal to comment specifically on the effect of the MFN clause, ${ }^{162}$ Canada and the two non-disputing parties stated their view that the MFN clause could not override or alter the meaning of Article 1105. For its part, Canada answered that the FTC interpretation was binding and that NAFTA Article 1103 could not undo that interpretation. ${ }^{163}$ The same day, the United States and Mexico filed non-party submissions under NAFTA Article 1128 agreeing that "Article 1103 cannot be relevant to, or constitute an issue with respect to, the interpretation of Article 1105."164

The United States subsequently sent to the Pope \& Talbot tribunal another non-disputing party submission, which attached a letter it had recently filed in its capacity as respondent in the Methanex case. ${ }^{165}$ The Methanex letter stated, with respect to Article 1103:

Methanex fundamentally misconstrues the nature of Article 1103's provision for mostfavored-nation treatment in any event. Contrary to Methanex's suggestion, Article 1103 addresses not the law applicable in investor-state disputes, but the actual "treatment" accorded with respect to an investment of another Party as compared to that accorded to other foreign-owned investments. Article 1103 is not a choice-of-law clause. Instead, it provides that each NAFTA Party shall accord to investors and their investments of other NAFTA Parties "treatment no less favorable than that it accords, in like circumstances" to investors or their investments of any other NAFTA Party or non-NAFTA Party "with respect to the establishment, acquisition, expansion, management, conduct, operation, and sale or other disposition of investments." Thus, Methanex errs in relying on Article 1103 because it offers neither evidence nor argument to show that a foreignowned investment allegedly in like circumstances was treated by the United States

${ }^{159}$ Pope \& Talbot Inc. v. The Government of Canada, UNCITRAL [hereinafter Pope \& Talbot], Award on the Merits of Phase 2, paras. 117-18 (Apr. 10, 2001) [hereinafter Pope \& Talbot 2001 Award].

${ }^{160} I d$., para. 117.

${ }^{161}$ NAFTA Free Trade Commission, Notes of Interpretation of Certain Chapter 11 Provisions, Section B (July 31, 2001).

162 Pope \& Talbot, supra note 159, Letter from the Honorable Lord Dervaird to the Parties, at 2 (Aug. 14, 2001); Pope \& Talbot, supra note 159, Letter from Honorable Lord Dervaird to the Parties (Sept. 17, 2001).

${ }^{163}$ Pope \& Talbot, supra note 159, Letter from Canada to the Tribunal, at 3 (Oct. 1, 2001).

${ }^{164}$ Pope \& Talbot, supra note 159, Sixth Submission of the United States of America, para. 2 (Oct. 2, 2001); Pope \& Talbot, supra note 159, Submission of the United Mexican States Pursuant to Article 1128 of the NAFTA (Oct. 1, 2001).

${ }^{165}$ Pope \& Talbot, supra note 159, Eighth Submission of the United States (Dec. 3, 2001). 
more favorably than it or its U.S. investments. . . A At bottom, Methanex urges this Tribunal to disregard the NAFTA Parties' binding interpretation and, instead, by virtue of Article 1103, interpret Article 1105(1) in accordance with its own view of BIT language, which has never been accepted by any arbitral tribunal and is contrary to the United States' contemporaneous statements regarding the BITs. Such a position is not consistent with the most-favored-nation treatment obligation of Article 1103. ${ }^{166}$

Canada also filed a non-disputing party submission in the Methanex case, stating that "[n]othing in the language of NAFTA Chapter Eleven permits a Chapter Eleven tribunal to import into Article 1105 separate and distinct obligations found in other agreements."167 The final award in Methanex did not address this issue.

In its subsequent award on damages, the Pope \& Talbot tribunal also declined to finally rule on the issue. Instead, the tribunal determined that Canada would have breached NAFTA Article 1105 even if the FTC's interpretation were to be given effect. ${ }^{168}$ But the position of the United States and Canada was clear: the MFN clause in Article 1103 could not be used to circumvent the parties' binding interpretation of the standards of treatment set forth in Article 1105.

\section{Chemtura v. Canada}

The issue arose again in Chemtura $v$. Canada. In that case, all three NAFTA states objected to the claimant's attempt to import “free-standing" FET clauses contained in Canada's BITs to supplement the minimum standard of treatment set forth in NAFTA Article 1105(1).

Canada's submissions in this case featured an extensive discussion of the elements of the NAFTA's MFN provision. ${ }^{169}$ This discussion came in reaction to what Canada perceived as an attempt by the claimant to "set[] aside the text of Article 1103" and instead to rely "on a broad purposive interpretation of MFN clauses generally." 170 Canada disagreed with that top-down approach, emphasizing that " $[\mathrm{t}]$ he general purpose of MFN provisions cannot serve to get around the specific terms of the MFN provision" agreed by the parties, and it set out to interpret those specific terms. ${ }^{171}$ First, Canada argued that the term "treatment," as ordinarily understood, referred to "behaviour in respect of an entity or a person," and that this definition did not encompass general treaty standards such as FET. ${ }^{172}$ Canada distinguished such "treatment," which was covered by the clause, from "standards of treatment,"

\footnotetext{
${ }^{166}$ Methanex Corporation v. United States of America, UNCITRAL [hereinafter Methanex], Response of Respondent United States of America to Methanex's Submission Concerning the NAFTA Free Trade Commission's July 31, 2001 Interpretation, at 9, 11 (Oct. 26, 2001) (emphasis in original).

${ }_{167}$ Methanex, supra note 166, Third-Party Submission of Canada Pursuant to NAFTA Article 1128, para. 11 (Feb. 8, 2002).

${ }^{168}$ Pope \& Talbot, supra note 159, Award in Respect of Damages, para. 66 (May 31, 2002). Despite this statement, the tribunal reiterated its views on Article 1103 in a footnote. Id., n. 54. In contrast to its analysis of MFN, the tribunal in Pope \& Talbot emphasized the "like circumstances" requirement when dealing with the claimant's national treatment claim, rejecting the claim on the ground that the claimant had failed to meet that requirement. See Pope \& Talbot 2001 Award, supra note 159, paras. 73-104.

${ }^{169}$ Chemtura, supra note 157, Canada's Counter-Memorial, paras. 861-911 (Oct. 20, 2008) [hereinafter Chemtura, Canada's Counter-Memorial]; Chemtura, Canada's Rejoinder, supra note 157, paras. 234, 236, 238-41.

${ }^{170}$ Chemtura, Canada's Rejoinder, supra note 157, para. 232.

${ }^{171}$ Id., para. 233.

172 Chemtura, Canada's Counter-Memorial, supra note 169, paras. 875-76.
} 
which "may potentially or theoretically result in a more favourable treatment of an investor from another Party or of a non-Party." 173 Canada continued:

There must be evidence of actual, not merely hypothetical, more favourable treatment. This does not render the MFN provision meaningless as the Claimant suggests. The NAFTA MFN provision does not simply allow the investor to choose the language it prefers from Canada's various investment agreements. The Claimant's MFN case relies on a purely theoretical argument that there exists a different more favourable standard in Canada's post-NAFTA investment agreements that would apply in like circumstances to certain other foreign investors. In reality, no national from a third country received better treatment. ${ }^{174}$

Canada also referred to the other textual elements of Article 1103, which it argued had also not been met. It argued that the claimant had failed to identify any investor "in like circumstances," relying instead on a mere comparison of treaty provisions. ${ }^{175}$ Canada also pointed to the specific wording of Article 1103-which applied to management, acquisition, sale, and other specified activities - and noted that this language made the clause narrower than the provisions addressed in MTD and other arbitral decisions. ${ }^{176}$

Moreover, Canada argued that the term "treatment" in Article 1103 had to be read in the context of Article 1101(1), which states that Chapter 11 of the NAFTA applies to "measures adopted or maintained by a Party," and Article 201, which defines "measure" as including a "law, regulation, procedure, requirement or practice." 177 In Canada's view, this meant that the scope of the MFN clause was limited to an "action taken by a single NAFTA government in its domestic jurisdiction," and that a treaty between two or more states "does not fall within the definition of measure and is not treatment for the purposes of Chapter 11."178

Both the United States and Mexico filed non-disputing party submissions in that case. Mexico expressed agreement with Canada's arguments on this issue and concluded that "the MFN obligation under Article 1103 cannot alter the substantive content of the fair and equitable treatment obligation under Article 1105(1)."179 The United States emphasized the agreement between all three NAFTA parties on the application of the MFN clause in this context, stating:

[A]ll three Parties later confirmed, through subsequent submissions commenting on that interpretation, that the MFN obligation under Article 1103 did not alter the substantive content of the fair and equitable treatment obligation under Article 1105(1). ${ }^{180}$

173 Chemtura, Canada's Rejoinder, supra note 157, para. 238.

${ }^{174}$ Id., paras. 239-40.

175 Chemtura, Canada's Counter-Memorial, supra note 169, para. 887; see also Chemtura, Canada's Rejoinder, supra note 157, paras. 236, 238 (arguing that the "in like circumstances" language "must be given meaning and take into account the circumstances relevant to the treatment at issue").

176 Chemtura, Canada's Counter-Memorial, supra note 169, paras. 861, 867, 906; Chemtura, Canada's Rejoinder, supra note 157, para. 234.

177 Chemtura, Canada's Counter-Memorial, supra note 169, paras. 875-78.

${ }^{178} I$ d., para. 878.

${ }^{179}$ Chemtura, supra note 157, Submission of Mexico Pursuant to Article 1128 of NAFTA, paras. 2-5 (July 31, 2009).

180 Chemtura, supra note 157, Submission of the United States of America, para. 5 (July 31, 2009). 
In its award, the Chemtura tribunal noted that the NAFTA states "firmly oppose" this use of MFN but declined to rule on the issue. ${ }^{181}$

\section{Subsequent Cases}

Following Chemtura, the NAFTA parties' views were recorded in Bilcon v. Canada, ${ }^{182}$ Apotex v. United States, ${ }^{183}$ and Mesa Power v. Canada, ${ }^{184}$ though again none of the tribunals in those cases directly ruled on the issue. ${ }^{185}$

In Mesa Power, for instance, Canada argued as follows:

Article 1103 is not a tool through which an investor can choose the language it prefers from Canada's various investment agreements. To prove a breach of Article 1103, the Claimant has the burden of providing evidence of actual — not hypothetical — treatment of an investor of a third party to the dispute. Otherwise, it would be impossible for the Tribunal to answer the necessary factual questions, such as whether the treatment was in fact "more favourable" and whether it was accorded in "like circumstances."186

In the same arbitration, Mexico took a similar position in a submission that echoed Canada's arguments in Chemtura on the meaning of "treatment":

Article 1103 applies to actual instances of treatment accorded to one or more investors of a third State, or their investments, which is more favorable than the treatment accorded, in like circumstances, to the claimant or its investment. The fact that another treaty theoretically offers different treatment is insufficient to establish a violation of Article 1103.187

For its part, the United States argued in Apotex that the NAFTA parties' repeated resistance to the use of the MFN clause in Article 1103 to "alter the substantive content of the fair and equitable treatment obligation under Article 1105(1)" had by this point come to reflect the "common, concordant views of all of the States Parties." 188 As such, this position "may be

${ }^{181}$ Chemtura, supra note 157, Award, paras. 235-36 (Aug. 2, 2010) (“The Respondent as well as the United States and Mexico in their Article 1128 interventions firmly oppose of the possibility of importing a FET clause from a BIT concluded by Canada.").

182 William Ralph Clayton, William Richard Clayton, Douglas Clayton, Daniel Clayton and Bilcon of Delaware Inc. v. Government of Canada, UNCITRAL, PCA Case No. 2009-04, Canada's Counter-Memorial, para. 312 (Dec. 9, 2011) (“All three NAFTA Parties have consistently rejected this proposition .....”).

${ }^{183}$ Apotex, supra note 39, Counter-Memorial on Merits and Objections to Jurisdiction of Respondent United States of America, para. 389 (Dec. 14, 2012) [hereinafter Apotex, United States' Counter-Memorial].

${ }^{184}$ Mesa Power Group, LLC v. Government of Canada, UNCITRAL, PCA Case No. 2012-17 [hereinafter Mesa Power], Canada's Rejoinder on the Merits, paras. 42, 152 (July 2, 2014) [hereinafter Mesa Power, Canada's Rejoinder]; Mesa Power, Submission of Mexico Pursuant to NAFTA Article 1128, para. 13 (July 25, 2014) [hereinafter Mesa Power, Mexico's Non-disputing Party Submission].

185 See, e.g., Apotex, supra note 39, Award, paras. 9.66-.71 (Aug. 25, 2014) (finding that the provision the claimant sought to import was not shown to be more favorable and declining to decide the broader issue of importation); Mesa Power, supra note 184, Award, paras. 400-03 (Mar. 24, 2016) (finding that Article 1103 did not apply because the claims related to procurement, which is expressly excluded from the scope of the MFN clause in accordance with NAFTA Article 1108(7)). The Bilcon award does not discuss this issue.

${ }^{186}$ Mesa Power, Canada's Rejoinder, supra note 184, para. 42.

187 Mesa Power, Mexico's Non-disputing Party Submission, supra note 184, para. 13 (emphasis in original).

${ }^{188}$ Apotex, United States' Counter-Memorial, supra note 183, para. 389. 
deemed the authentic interpretation of the treaty," which must be taken into account by NAFTA tribunals. ${ }^{189}$

\section{B. Limitations on MFN Clauses in Recent Investment Treaties}

Beyond arbitral disputes, some states have sought to curtail the use of MFN provisions to import standards of treatment in recently concluded treaties, drafts, and model clauses. This is frequently accomplished by introducing language that is clearly designed to overcome any presumption in favor of importation, or by clarifying certain basic terms of the MFN clause_-such as "treatment" and "like circumstances" — in ways that expressly or implicitly preclude importation.

For example, the MFN clause in the investment chapter of the EU-Canada Comprehensive Economic and Trade Agreement (CETA) expressly provides that the clause may not be used to import either dispute settlement provisions or standards of treatment:

For greater certainty, the "treatment" referred to in paragraphs 1 and 2 does not include procedures for the resolution of investment disputes between investors and states provided for in other international investment treaties and other trade agreements. Substantive obligations in other international investment treaties and other trade agreements do not in themselves constitute "treatment," and thus cannot give rise to a breach of this Article, absent measures adopted or maintained by a Party pursuant to those obligations. ${ }^{190}$

Similar clarifications can be found in the MFN clause of the draft EU-Japan Economic Partnership Agreement, ${ }^{191}$ the draft Pan-African Investment Code, ${ }^{192}$ and the Protocol of Cooperation and Intra-Mercosur Investment Facilitation signed in 2017. ${ }^{193}$

${ }^{189}$ Id.

${ }^{190}$ Comprehensive Economic and Trade Agreement, EU-Can., 2016, Art. 8.7, available at http://data.consilium.europa.eu/doc/document/ST-10973-2016-INIT/en/pdf; see also Dumberry, Shopping For a Better Deal, supra note 4, at 16 (discussing the implications of the provision); Frank Hoffmeister \& Gabriela Alexandru, $A$ First Glimpse of Light on the Emerging Invisible EU Model BIT, 15 J. World Inv. \& Trade 379, 387-88 (2014) (discussing the "expansive case-law" in Maffezini and Bayindir and arguing that "excluding the incorporation of other normative standards into the operation of an MFN clause is actually preserving the political freedom of the EU to strive for the best available standards on the basis of full reciprocity with all its treaty partners"); cf. European Commission, Public Consultation on Modalities for Investment Protection and ISDS in TTIP (Mar. 2014), available at http://trade.ec.europa.eu/doclib/docs/2014/march/tradoc_152280.pdf (stating, in connection with the Transatlantic Trade and Investment Partnership, that “[o]n the 'importation of standards' issue, the EU seeks to clarify that MFN does not allow procedural or substantive provisions to be imported from other agreements").

${ }^{191}$ Draft Economic Partnership Agreement, EU-Japan, July 2017, Art. [x4] (5), available at http://trade.ec. europa.eu/doclib/docs/2017/july/tradoc_155710.pdf ("Substantive provisions in other international agreements concluded by a Party with a non-Party do not in themselves constitute 'treatment' under this Article."); see also Robert Howse, Fumbling Towards Multilateralism? A First Read of the Investment Text in the Japan-EU FTA, INT'L ECON. L. \& POL'y BlOG, July 7, 2017 (discussing these provisions).

192 Draft Pan-African Investment Code, Art. 7, 2016, available at http://repository.uneca.org/bitstream/handle/10855/23009/b11560526.pdf?sequence=1 ("For greater certainty, the 'treatment,' referred to in Paragraphs 1 and 2 [the MFN provisions], does not include dispute settlement procedures provided for in other treaties. Substantive obligations in other treaties, do not in themselves constitute 'treatment,' and thus cannot give rise to a breach of this Article.").

193 Protocol of Cooperation and Intra-Mercosur Investment Facilitation, Art. 5.7, Apr. 7, 2017, available at http://apc.mef.gub.uy/innovaportal/file/21186/2/protocolo-de-cooperacion-y-facilitacion-de-inversiones.pdf 
It is not yet clear what effect these new clauses will have on the prevailing approach to MFN. One leading treatise, seemingly playing down the new CETA provision, states:

In Article X.7(4) of CETA, Canada and the European Union agree that "[s]ubstantive obligations in other international investment treaties and other trade agreements do not in themselves constitute 'treatment,' and thus cannot give rise to a breach of this article, absent measures adopted by a Party pursuant to such obligations." This provision must be taken to be lex specialis. As a matter of general international law, a treaty obligation assumed towards a third State may constitute treatment for the purpose of the MFN clause. ${ }^{194}$

The reference to lex specialis in this passage is imprecise, as there is no MFN standard applicable "as a matter of general international law" from which the CETA seeks to derogate. ${ }^{195}$ It is likely that the authors instead meant to suggest a variation of the top-down approach discussed above: that is, that the CETA provision is a specialized formulation, which, outside the context of this specific treaty, does not alter the essential nature of the MFN standard. ${ }^{196}$

So restated, this view raises the further question of how states would go about altering the general presumptions about the nature of MFN treatment in investment treaties. The answer to this question would seem to depend on whether these developments in treaty drafting are understood as specialized deviations from standard practice or as attempts at clarification. Some commentators have taken the latter view, referring to these recent clauses as attempts to avoid "unintended consequences" arising from tribunal interpretations of earlier clauses. ${ }^{197}$ For instance, the commentary to the new Southern African Development Community Model BIT Template states:

The Drafting Committee noted that these should be bilateral treaties and that, as such, they should not establish unintended multilateralization through the MFN provision.... The Committee also noted that the MFN provision has been very broadly, and on several occasions unexpectedly, interpreted in arbitrations, making it very unpredictable in practice. This poses unnecessary risks for States, especially developing countries. ${ }^{198}$

("For greater certainty, the provisions of this Article [which includes the MFN clause] shall not apply to incorporate provisions either substantive or relating to dispute settlement not contained in the present Protocol.”) (authors' translation); see also id. Art. 5.6; Southern African Development Community Model Bilateral Investment Treaty Template with Commentary, Art. 4.4, July 2012, available at http://www.iisd.org/itn/wp-content/uploads/2012/10/sadc-model-bit-template-final.pdf ("Notwithstanding any other provision of this Agreement, the provisions of this Article shall not apply to concessions, advantages, exemptions or other measures that may result from: (a) a bilateral investment treaty or free trade agreement [that entered into force prior to this agreement]. . ...") [hereinafter SADC Model BIT].

${ }^{194}$ McLachlan, Shore \& Weiniger, supra note 34, para. 7.308.

${ }^{195}$ As noted supra in Part I.A., the MFN standard is not a creature of customary international law and is effected only through treaties. The principle of lex specialis presumes two applicable legal rules, and it provides that, in case of conflict, the general rule shall give way to the specific one. See, e.g., Martti Koskenniemi, Fragmentation of International Law, Report of the Study Group of the International Law Commission, paras. 56-87, UN Doc. A/CN.4/L.682 (Apr. 13, 2006).

196 See supra Part I.A.

197 Titi, supra note 12, at 434 (2016) (suggesting this in the context of the EU-Canada Comprehensive and Economic Trade Agreement (CETA)); see also Venezuela US, S.R.L. v. The Bolivarian Republic of Venezuela, UNCITRAL, PCA Case No. 2013-34, para. 56 (July 26, 2016) (Kohen, dissenting) (arguing that the MFN clause of the CETA illustrates "the discontent of States to the extensive interpretations of these clauses").

198 SADC Model BIT, supra note 193, commentary to Art. 4. 
The new clarification in CETA and other treaties, moreover, is only one possible reaction to what states see as overbroad or troubling interpretations of MFN clauses. For example, certain states have imposed other temporal or substantive limitations on MFN clauses in their recent treaties. ${ }^{199}$ For its part, India has simply omitted MFN from its most recent model investment treaty. ${ }^{200}$ India has also sent a draft joint interpretative statement to twenty-five BIT partners in which it proposed to clarify that "the MFN obligation is not intended to alter the Agreement's substantive content by, for example, permitting piecemeal incorporation of and reliance on provisions found in other treaties, investment or otherwise." 201 The draft interpretative statement also states that a breach of the MFN clause "requires a comparison between investors and investments that are in 'like circumstances" and sets forth an extensive list of factors to be used for a "fact-specific" assessment of whether the requirement of "like circumstances" has been met. ${ }^{202}$

By widening the frame beyond published investment arbitral awards, the foregoing discussion places the MFN debate in a new light. In response to the above trends, it is not so easy to accept, as many arbitral awards have done, the conventional wisdom that an MFN clause may always be used to import substantive standards of treatment from other treaties. To be sure, the parties may conclude MFN clauses that have this effect if they wish to do so. But it is incumbent on practitioners and tribunals to be more careful in determining whether and to what extent states have agreed to such a use of MFN in any given treaty.

\section{Concluding Remarks on the Terms of the New MFN Debate}

The time has come to engage in a serious debate regarding the use of MFN clauses to import standards of treatment from one investment treaty to another. For too long, arbitral

${ }^{199}$ See, e.g., Agreement for the Promotion and Reciprocal Protection of Investments, Slovk.-Iran, Art. 4.5, Jan. 19, 2016, available at http://investmentpolicyhub.unctad.org/Download/TreatyFile/3601 (the MFN clause "shall not apply to ... treatment by the Contracting Party under any bilateral or multilateral international agreement in force or signed by the Contracting Party prior to the date of entry into force of this Agreement"); Treaty for the Reciprocal Promotion and Protection of Investments, Arg.-Qatar, Art. 4(4), Nov. 6, 2016, available at http:// investmentpolicyhub.unctad.org/Download/TreatyFile/5383 (the MFN clause "shall not apply in order to invoke the fair and equitable treatment and the dispute settlement provisions accorded to investors of any Third State under treaties signed by one of the Contracting Parties prior to the entry into force of this Treaty"); Free Trade Agreement, EU-Singapore, Chapter Nine (Investment), authentic text as of May 2015, available at http://trade.ec.europa.eu/doclib/docs/2014/october/tradoc_152844.pdf (omitting MFN treatment, except in connection with compensation for losses owing to armed conflict, insurrection, revolution and other such circumstances (Art. 9.5)).

${ }^{200}$ See Model Text for the Indian Bilateral Investment Treaty, Chapter II, 2015, available at https://www. mygov.in/sites/default/files/master_image/Model\%20Text\%20for\%20the\%20Indian\%20Bilateral\%20Invest ment\%20Treaty.pdf. Reports suggest that this may have been in response to the tribunal's decision to import an "effective means" clause in White Industries. Ashutosh Ray, New Indian Model BIT on the Anvil, KLuwEr ArB. BLOG (Jan. 9, 2015) (predicting that the new Indian model BIT would limit or remove the MFN clause, in light of the state's loss in White Industries).

${ }^{201}$ Investment Division of the Department of Economic Affairs of India's Ministry of Finance, Office Memorandum on Issuance of Joint Interpretative Statements for Indian Bilateral Investment Treaties, Note 9(2)(a), Feb. 8, 2016, available at http://indiainbusiness.nic.in/newdesign/upload/Consolidated_Interpretive-Statement. pdf.

${ }^{2} 02$ Id. at Note 9(3)(b). India and Bangladesh reportedly agreed to enter into a joint statement that largely mirrors India's draft. Jarrod Hepburn, Unable to Unilaterally Terminate a 2011 BIT, the Government of India Persuades Counter-party to Agree Joint Interpretive Note to Clarify BIT's Implications, InVESTMENT ARB. ReP. (July 17, 2017); Douglas Thomson, India's BIT Recast Continues, Global Arb. Rev. (July 19, 2017). 
tribunals have simply assumed that this practice was permitted under the MFN clause at issue, or have paid only limited attention to the treaty text. ${ }^{203}$ This debate will be best served if we bracket, for the time being, presumptions about the essential nature and function of MFN clauses in this respect, and turn instead to the specific terms of the treaties in which these clauses appear.

In these concluding remarks, we do not purport to offer our own general theory of MFN clauses, except perhaps to recommend greater caution in the face of such theories. Rather, we highlight some issues which should be central to the new MFN debate, and which have until recently been obscured by the conventional wisdom. These issues include the extent to which emerging trends in drafting should affect the interpretation of earlier treaties, the meaning of common terms in investment treaties (such as "treatment" and "similar situations"), and the reconsideration of the relationship between MFN clauses and the purposes of investment treaties.

\section{A. Treaty Drafting and Treaty Interpretation}

As states continue to develop more precise language on MFN in their newer treaties, tribunals will have to consider to what extent these developments may affect their interpretations of earlier treaties. As noted above, it may be debated in any particular case whether the "new generation" MFN provisions represent departures from earlier negotiating positions or clarifications of what was always intended by earlier MFN clauses.

This debate must take into account both general arguments about the nature of iterative treaty practice and specific arguments about individual treaty clauses. At a general level, tribunals and commentators have already begun to grapple with the implications of the clarifying language that has been adopted in some, but not all, more recent treaties. ${ }^{204}$ For instance, in the context of the "old" MFN debate, the Plama tribunal found that the insertion in post-Maffezini treaties of language excluding the importation of dispute settlement provisions via MFN reflects "a reaction by States to the expansive interpretation made in the Maffezini case" and that "[i]f such language is lacking in an MFN provision, one cannot reason a contrario that the dispute resolution provisions must be deemed to be incorporated."205 Likewise, the tribunal in Daimler viewed such language as "signaling that the specified MFN clauses do not, and were never intended to, reach the international dispute resolution provisions of the respectively mentioned investment agreements."206

At a more granular level, tribunals may also have to address provisions in subsequent treaties that purport to clarify preexisting agreements. For example, it has been contended that language such as "for greater certainty" is included in later treaties to signal that the provision is meant to clarify established meanings, rather than signal a change in direction. ${ }^{207}$

\footnotetext{
203 See supra Part II.

${ }^{204}$ See UNCTAD MFN Report, supra note 10, at 95 ("[T] he fact that a country has not reacted through changes in their model treaty or new treaty drafting does not necessarily mean an implicit agreement with the broad and furthermore inconsistent interpretations by arbitral tribunals ...."); Kinnear, supra note 40, at 52 (“[S] ome might debate whether respondents should be held to a different standard in pre- and post-Maffezini treaties on the logic that the concern about clarity in drafting must have become patent at some point after the Maffezini award.").

205 Plama, supra note 46, para. 203.

206 Daimler, supra note 86, para. 276.

207 See, e.g., James Mendenhall, The Evolution of the Essential Security Exception in U.S. Trade and Investment Agreements, in Sovereign Investment 310, 341 (Karl P. Sauvant, Lisa E. Sachs \& Wouter P. F. Schmit Jongbloed
} 
The weight that tribunals give to these recent developments in treaty-making may impact not only the outcome of individual cases, but also the ability of states to affect and reshape overarching views of "the MFN standard." This debate will therefore be particularly important if tribunals continue to apply any kind of top-down approach to the interpretation of MFN clauses.

\section{B. Renewed Attention to Specific Treaty Terms}

If interpreters bracket their presumptions and intuitions about the nature of MFN clauses and MFN importation, they will need to pay closer attention than they have in the past to particular terms in MFN clauses.

This reconsideration of treaty terms must begin with the scope of the term "treatment." Some states have expressed the view that "treatment," as it is used in at least some investment treaties, refers to actual measures taken vis-à-vis investors or investments, and not to "standards of treatment" afforded in other investment treaties. ${ }^{208}$ It has been suggested that states, when drafting the earlier-generation investment treaties, did not envision that these provisions would apply to import standards of treatment but rather that they would forbid actual discrimination through conduct by the host state- what has been described as the "traditional" use of MFN clauses. ${ }^{209}$ One investment treaty negotiator defended a similar position in a 2008 article, and argued that MFN clauses generally "should not be used for treaty shopping purposes." 210

This approach would have tribunals draw a distinction between "treatment" and "standards of treatment." As a conceptual matter, this view is consistent with a growing body of literature that identifies general treaty standards such as FET as "standards of review" against which certain state measures are assessed. ${ }^{211}$ On this view, it might be argued, "treatment" refers to the state measure under review in an FET claim, rather than the FET provision itself. This argument remains under-explored, and there is little discussion on how the distinction

eds., 2012) (stating that the expression "for greater certainty" implies "that it merely clarifies but does not substantively change the meaning of the basic provision").

${ }^{208}$ See, e.g., supra Part III (discussing the respondent state's position in $\dot{I}_{c ̧} k a l e$ ), Part IV.A (discussing submissions in NAFTA cases) and Part IV.B (discussing clarifying provisions in the CETA and other treaties).

${ }^{209}$ Suzy H. Nikièma, The Most-Favoured-Nation Clause in Investment Treaties, IISD Best Practice SerIes 21 (Feb. 2017) (“ $[\mathrm{I}] \mathrm{t}$ is hard to believe that, when signing BITs before 2000, states would have envisaged MFN being used to import provisions from BITs with other countries, whether substantive or procedural rules. It is more likely that they were referring to treatment directly granted in the host country."); Sundaresh Menon, The Transnational Protection of Private Rights: Issues, Challenges, and Possible Solutions, 108 ASIL Proc. 219, 232-33 (2015) (noting that broad interpretations of MFN clauses that allow investors to "pick and choose" provisions from third-party treaties may enable an investor "to construct a cause of action that might never have been in the contemplation of the contracting states" and that "[ $\mathrm{t}]$ he obligations of the contracting states might therefore be defined by a patchwork of the most favorable provisions contained in a raft of treaties linked by MFN clauses_-potentially undermining the calibrated result of inter-state negotiations"); see also supra Part I.A.

210 Rodriguez, supra note 64, at 96, 101.

211 See Rahim Moloo \& Justin M. Jacinto, Standards of Review and Reviewing Standards, in Y.B. INT'L Investment L. \& Pol'y 2011-2012, at 539, 542-43, 552 (Karl P. Sauvant ed., 2013); Anna T. Katselas, Do Investment Treaties Prescribe a Deferential Standard of Review?, 34 Mich. J. INT'L L. 87, 90, 117-18 (2012); Todd J. Grierson-Weiler \& Ian A. Laird, Standards of Treatment, in The Oxford Handbook OF International Investment LaW 259, 299-300 (Peter Muchlinski, Federico Ortino \& Christoph Schreuer eds., 2008); Gus Van Harten, Investment Treaty Arbitration and Public Law 80-81 (2007) [hereinafter VAN HaRTEN]. 
between treatment and standards might be applied to other provisions in investment treaties. $^{212}$

Tribunals will also have to consider more closely the other elements of MFN clauses. As

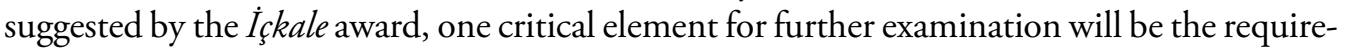
ment that the investor be "in like circumstances" or "in similar situations" with a suitable comparator. ${ }^{213}$ Other terms may include territorial limitations, ${ }^{214}$ as well as clauses directing the application of MFN provisions to specific activities, such as the maintenance, management, use, and acquisition of investments. ${ }^{215}$

These terms may be usefully treated as individual elements of a given MFN clause, but it also will be important to understand how they operate in concert to define the clause's scope.

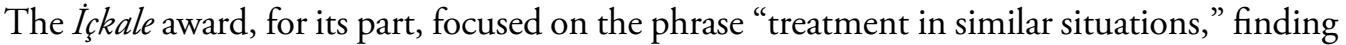
that this phrase did not extend to standards of treatment in other investment treaties. ${ }^{216}$ Thus the terms "in similar situations" could be said to operate not only as an element that must be

212 But see Rodriguez, supra note 64, at 101-02 (objecting as a general matter to the use of MFN clauses for treaty shopping, but suggesting that the MFN clause might address, at most, third-party treaty provisions that relate "to competitive conditions for investment; examples would be pre-establishment, transfers and performance requirements").

213 İckale, supra note 20, paras. 329, 332; see also Chemtura, Canada's Rejoinder, supra note 157, paras. 236, 238; ILC 2015 Report, supra note 17, para. 71 (noting that these terms "seem to place some limitation upon which investors or investments can claim the benefit of an MFN provision-suggesting perhaps that only those investors or investments that are in 'like circumstances' with those of the comparator treaty can do so"); Pia Acconci, MostFavoured-Nation Treatment, in The OXFord HandBoOK OF InTERNATIONAL InVESTMENT LaW, supra note 211, at 363, 365-66, 376-77 (recognizing the "restrictive" effect of the "like circumstances" language and arguing that MFN treatment "cannot apply if only investors of the same country have invested in another country" because "[i]n such a case there is no possibility of comparing the treatments granted by the same country to foreign investors coming from different countries").

${ }^{214}$ See, e.g., Beijing Urban Construction Group Co. Ltd. v. Republic of Yemen, ICSID Case No. ARB/14/30, Decision on Jurisdiction, paras. 116-17, 120 (May 31, 2017) (finding that an express limitation of the MFN clause to treatment accorded by the state in "its territory" "tie[s] the MFN to activities that take place "in the territory' associated geographically with the investment," and rejecting the claimant's attempt to use that MFN provision to import dispute settlement provisions from third-party treaties); Douglas, Off the Rails, supra note 2, at 111 ('A purely textual analysis [in RosInvest] would have run into difficulties with the words in its territory' that are to be found in each paragraph of the MFN clause. How can the host state provide more favourable treatment in relation to the scope of an international tribunal's jurisdiction 'in its territory'?"). This limitation has not been discussed in the context of standards of treatment, but, to the extent that standards of treatment are conceptualized as "standards of review," the same difficulties encountered by the Beijing Urban Construction tribunal could arise in this context as well.

215 See, e.g., Chemtura, Canada's Counter-Memorial, supra note 169, para. 861; ILC 2015 Report, supra note 17, para. 62 (distinguishing this language from other MFN provisions). In the context of dispute settlement, see Christopher F. Dugan, Don Wallace, Jr., Noah Rubins \& Borzu Sabahi, Investor-State Arbitration 416 (2008) (quoting Noah Rubins) (such clauses "are intended to cover the investment of the investor and/or its investment vehicle, i.e. matters related to making money, and not matters related to vindicating rights through international arbitration"), Vesel, supra note 3, n. 95 (stating that these textual limits to the scope of MFN "would clearly preclude its application to dispute settlement mechanisms"). Also compare Hochtief AG v. The Argentine Republic, ICSID Case No. ARB/07/31, paras. 61-68 (Oct. 7, 2011) (Thomas, dissenting) (finding that an MFN clause referring to the "management, exploitation, use and enjoyment" of investments was "concerned only with a specific genus of less favourable treatments and in relation to a specific genus of investor activities," namely "measures" affecting the "the day-to-day management and operation of the investment," and thus could not be invoked to import dispute settlement provisions from third-party treaties), with Hochtief AG v. The Argentine Republic, ICSID Case No. ARB/07/31, Decision on Jurisdiction, paras. 65-66 (Oct. 24, 2011) (holding that dispute settlement was "as an aspect of the management of the investment" and therefore the MFN clause could be used to import dispute settlement provisions).

${ }^{216} \dot{I}_{\text {çkale, supra note 20, para. } 329 .}$ 
satisfied in an MFN claim, but also as part of the context guiding the interpretation of the scope of the clause as a whole.

\section{MFN and the Nature of Nationality-Based Discrimination in Investment Treaties}

The new MFN debate also provides an opportunity to reconsider prevailing theories about the purpose of these clauses in investment treaties. Greater emphasis on the specific terms of MFN clauses — such as "like circumstances" and "similar situations" — will naturally bring the MFN analysis into closer contact with the analysis under similarly worded "national treatment" provisions. ${ }^{217}$ The interplay between these two standards may inform arguments as to the overall role of "non-discrimination" provisions in investment treaties, and the type of discrimination to which these provisions are addressed.

There are at least two potential approaches to understanding "discrimination" in the context of these provisions. The view of MFN clauses as instruments of multilateralization comes with a built-in understanding of the purpose of investment treaties as a means to impose "uniform standards of investment protection which, in turn, allow investors from different national origins to compete under equal competitive conditions." 218 On this view, "discrimination" is potentially anything that imposes unequal transaction costs for investors based on their nationality. ${ }^{219}$ The focus of the multilateralization view on competition aligns, in this sense, with areas of international trade jurisprudence, which emphasize "equal competitive opportunities" without regard to the actual effects of state measures. ${ }^{220}$

A second view of discrimination, which is arguably more prevalent in the context of national treatment claims under investment treaties, is concerned with repairing the effects of actual discrimination on specific investments, not equalizing abstract competitive opportunities. ${ }^{221}$ Investment tribunals dealing with national treatment claims have thus adopted an

217 See, e.g., Jürgen Kurtz, The MFN Standard and Foreign Investment: An Uneasy Fit?, 5 J. WorLd INV. \& TRADE 861, 875 (2004) (noting similarities in the two standards and suggesting that OECD guidance on national treatment could provide "a useful starting point" for examining similar problems in MFN cases) [hereinafter Kurtz]; ILC 2015 Report, supra note 17, para. 77 ("In the view of the Study Group, interpretations of phrases such as 'in like circumstances' or 'in similar situations' in the context of national treatment can provide important guidance for the interpretation of those terms in the context of MFN clauses.").

218 Schill, supra note 5 , at 500 .

219 See id. at 503 ("Complemented by national treatment, the economic rationale of MFN treatment is to create a level playing field for all foreign investors by prohibiting discrimination between investors from different home States. It aims at enabling equal competition among investors by prohibiting the imposition of different transaction costs based on the national origin of investors. Equal competition, in turn, is essential for the functioning of a market economy that helps to allocate resources efficiently. Thus, MFN treatment reflects the crucial importance competitive structures play for efficient investment and an efficient allocation of resources.").

${ }^{220}$ Cf. Appellate Body Report, Japan-Taxes on Alcoholic Beverages, WTO Doc. No. WT/DS8/AB/R, at 16 (Oct. 4, 1996) ("[I]t is irrelevant that 'the trade effects' of the tax differential between imported and domestic products, as reflected in the volumes of imports, are insignificant or even nonexistent; Article III protects expectations not of any particular trade volume but rather of the equal competitive relationship between imported and domestic products.").

${ }^{221}$ Nicholas DiMascio \& Joost Pauwelyn, Nondiscrimination in Trade and Investment Treaties: Worlds Apart or Two Sides of the Same Coin?, 102 AJIL 48, 70-71 (2008) [hereinafter DiMascio \& Pauwelyn]. On the difference between trade and investment rules in non-discrimination and other areas, see, for example, Ziegler, supra note 34, at 59, 86 (noting differences in the questions relating to MFN treatment in the trade and investment contexts, and observing that the trade regime "is full of exceptions such as those relating to regional trade agreements ... and preferences accorded to developing countries," which "usually prevents the States from invoking dispute settlement provisions or other procedural or substantive rules from FTAs or agreements on double taxation, etc, in the WTO context"); Cole, supra note 16, at 553 (arguing that "international investment law by its nature has far 
approach that generally rejects "the trade law emphasis on alteration of the conditions of competition" and instead favors "a test that focuses on whether an alleged discrimination is effectively based upon nationality rather than some other policy reason."222

These two views of discrimination suggest different understandings of the purpose of MFN clauses in investment treaties, and hence raise different questions regarding MFN importation. For the multilateralization view, the key question may be whether variations among treaty standards do, as a general matter, impact competitive opportunities. ${ }^{223}$ For the latter view, however, the question arguably is whether a variance in applicable standards of treatment is capable, on its own, of having an "actual impact on, or harm to, a specific investor or investment." 224 A closer consideration of individual MFN clauses, read in context with accompanying national treatment provisions, could provoke a debate as to which of these conceptions of discrimination applies, and what consequences that has for MFN importation.

\section{Between Formalism and Ideology}

The new MFN debate echoes broader shifts with respect to the interpretation of investment treaties. The presumption in favor of MFN importation is consistent with a teleological view that investment treaties are designed solely to maximize investor protection, ${ }^{225}$ a view that is now undergoing a sustained backlash. ${ }^{226}$ Efforts are underway in some fora to substitute the narrow focus on investment protection for a broader conception of the goals served by

greater effects upon state action than does the mere setting of tariff levels for imported products," therefore "failing to recognize the appropriate limits on the operation of MFN clauses within international investment law, and interpreting them solely in accordance with predetermined teleological goals, risks seriously impacting the appropriate regulatory activities of states"); Kurtz, supra note 217, at 862-72 (noting differences between the contexts of trade rules and investment rules); José E. Alvarez, The Public International Law Regime Governing INTERNATIONAL INVESTMENT 34-37 (2011) (noting, in other contexts, differences between the two regimes).

222 DiMascio \& Pauwelyn, supra note 221, at 75-76.

${ }^{223}$ Some writers have raised doubts about this effect. See Greenwood, supra note 2, at 557 (questioning whether there is a "direct effect" on competition that results solely from the uneven distribution of standards of protection across treaties); Rodriguez, supra note 64, at 101 (similar).

${ }^{224}$ DiMascio \& Pauwelyn, supra note 221, at 70; see also UNCTAD MFN Report, supra note 10, at 102 ("Assuming MFN treatment in investment agreements, the exercise should not entail an automatic importation but the undertaking of an assessment of whether the absence of the provision at stake actually causes a damage to the investor, for which the measure that gave rise to the dispute would have to be characterized as breaching said provision in the first place.").

${ }^{225}$ See, e.g., Part II.B.1 supra (discussing the MTD tribunal's importation of standards of treatment based on an interpretation "in the manner most conducive to fulfill the objective of the BIT to protect investments and create conditions favorable to investments").

${ }^{226}$ See, e.g., Zachary Douglas, Nothing if Not Critical for Investment Treaty Arbitration: Occidental, Eureko and Methanex, 22 ARB. INT'L 27, 51 (2006) ("An interpretive approach that systematically favours the interests of one of the disputing parties need only be articulated to be proven unsound."); VAN HARTEN, supra note 211, at 140 (arguing against a "presumption in favour of safeguarding the claimant against the state"); WEERAMANTRY, supra note 3, para. 7.24 ("A bias that unquestioningly requires interpretations to be made in favour of investors lacks the requisite degree of impartiality and undermines the legitimacy of the investor-State dispute resolution system.”); Alexander Orakhelashvili, The Interpretation of Acts and Rules in Public International Law 565 (2008) (similar); Anne van Aaken, Control Mechanisms in International Investment Law, in THE FoundATIONS OF Investment Law 409, 422 (Zachary Douglas, Joost Pauwelyn \& Jorge E. Viñuales eds., 2014) (noting tribunal decisions on either side of this issue, and questioning whether protection of investment is really the ultimate purpose of such treaties, which generally aim at other goals, such as economic cooperation, development, prosperity, and welfare). 
investment treaties. ${ }^{227}$ These counter-narratives are advanced to spark a reconsideration of the specific provisions of investment treaties, including the substantive standards of treatment afforded therein.

By insisting on renewed attention to the specific terms of MFN clauses, we suggest it is helpful to approach this debate from a new direction. The debate over grand narratives, as a general matter, hopes to proceed from a consideration of broad purposes to the interpretation of specific terms. The debate we have outlined here, by contrast, focuses on the details of MFN clauses. A turn to bottom-up approaches, to the treaty text, and to the formal rules of treaty interpretation may be particularly appropriate in times of deep ideological contestation. This approach frees the interpreter from having to rely on presumptions and received wisdom, without necessarily forcing him or her to embrace a competing ideology. ${ }^{228}$ By proceeding through case-by-case analysis of MFN clauses and of their role in the overall scheme of investment protection, tribunals and commentators may ultimately contribute to a richer and more nuanced understanding of investment treaties than could be achieved through topdown approaches.

\footnotetext{
${ }^{227}$ SADC Model BIT, supra note 193, commentary to preamble (enshrining in the preamble a broader set of purposes, in order to prevent tribunals from applying "a presumption in favour of broader over narrower rights for the investor").

${ }^{228}$ Cf. Robert Howse, The World Trade Organization 20 Years On, 27 Eur. J. INT'L L. 9, 30-33 (2017) (making a similar point in the context of the WTO).
} 